\title{
GİRIŞ̧IMCİ YÖNLÜLÜK,
}

\section{IC-GiRişiMciLiK VE ISLETME $\quad$ Hacettepe Unniversitesi

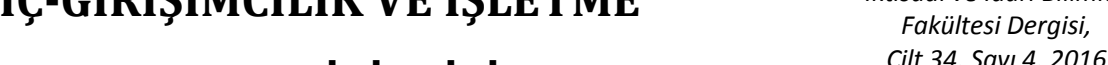

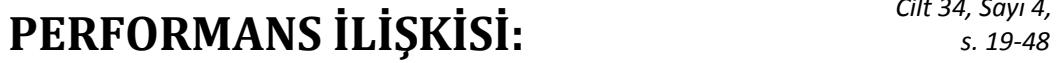

\section{TÜRKIYE TEKSTIL SEKTÖRÜ}

\section{İŞLETMELERİNDE BİR ARAŞTIRMA}

\author{
Gürcan PAPATYA \\ Yrd.Doç.Dr., Süleyman Demirel \\ Üniversitesi, İktisadi ve İdari Bilimler \\ Fakültesi \\ İşletme Bölümü \\ gurcanpapatya@sdu.edu.tr

\section{Nurhan PAPATYA} \\ Prof.Dr., Süleyman Demirel Üniversitesi \\ İktisadi ve İdari Bilimler Fakültesi \\ İşletme Bölümü \\ nurhanpapatya@sdu.edu.tr
}

\author{
Ahmet Buğra HAMŞIOĞLU \\ Dr., Kafkas Üniversitesi \\ İktisadi ve İdari Bilimler Fakültesi \\ İşletme Bölümü \\ ahbugra@hotmail.com
}

z: Bu çalışma İSO-500 listesinde yer
alan Türkiye tekstil sektör
işletmelerinin girişimci yönlülük ve
iç-girişimcilik faaliyetleri ile işletme
performansı arasındaki ilişkiyi belirlemeye yönelik görgül bir araştırmayı amaçlamaktadır. Girişimci yönlülük, içgirişimcilik ve işletme performansı olarak üç boyutlu tasarlanan çalışmada anket yöntemi kullanılmıştır. Anket 96 işletmeye 2015 ŞubatMart ayında faks ve e-mail yoluyla gönderilmiş; ankete katılımı kabul eden 51 işletmeden anket geri dönüşümü sağlanmıştır. 51 işletmeden elde edilen veriler değerlendirmeye alınmıştır. Veriler, SPSS 11.5 ve Lisrel 8.7 istatistiki programlar yardımıyla doğrulayıcı faktör analizi ve yapısal eşitlik model analizi ile test edilmiştir. Analizde araştırmada oluşturulan, "girişimci yönlülük işletme performansını pozitif etkiler" şeklindeki birinci hipotez ve "iç-girişimcilik işletme performansını pozitif etkiler" şeklindeki ikinci hipotez red edilmemek suretiyle, araştırma modeli doğrulanmıştır.

Anahtar Sözcükler: Girişimci yönlülük, içgirişimcilik, işletme performansl, Türkiye tekstil sektörü. 
ENTREPRENEURSHIP

\section{ORIENTATION, INTREPRENEURSHIP}

AND BUSINESS PERFORMANCE

\section{RELATIONSHIP: AN RESEARCH}

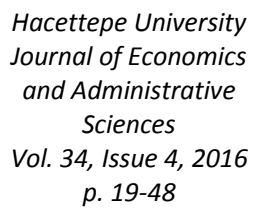

\section{IN THE TURKISH TEXTILE}

\section{SECTOR BUSINESS}

\section{Gürcan PAPATYA}

Assist.Prof.Dr., Süleyman Demirel

University

Faculty of Economics and Administrative

Sciences

Department of Business Administration gurcanpapatya@sdu.edu.tr

\section{Nurhan PAPATYA}

Prof.Dr., Süleyman Demirel University

Faculty of Economics and Administrative

Sciences

Department of Business Administration nurhanpapatya@sdu.edu.tr

\footnotetext{
Ahmet Buğra HAMŞIOĞLU

Dr., Kafkas University

Faculty of Economics and Administrative Sciences

Department of Business Administration ahbugra@hotmail.com
}

A

bstract: This study aims to do an empirical research on the relationship between the entrepreneurship and intrapreneurship activities of textile enterprises from Turkey's Top 500 Company List (İSO-500), and their business performances. The study is designed with the three dimensions as entrepreneurship, intrapreneurship and business performance and deployed a survey method. Survey was sent to 96 enterprises by fax and e-mail in February-March 2015; 51 enterprises agreed to participate in the study and sent the filled surveys back. The data obtained from the 51 enterprises were analyzed and tested by confirmatory factor analysis and structural equation model analysis using the statistical software programs SPSS 11.5 and Lisrel 8.7. The research model was verified by not rejecting the first hypothesis as "Entrepreneurship tendency positively effects business performance" and the second hypothesis as "Intrapreneurship positively effects business performance".

Keywords: Entrepreneurship orientation, intrapreneurship, firm performance, textile sector. 


\section{GíRIŞ}

Yaşanan hızlı değişim ve yeni rekabet koşullarında işletmeler faaliyetlerini girişimci eksenli yapma ve düzenleme ihtiyacı duymaktadır. Böylece hem rekabette önemli bir avantaj yaratmak, hem de performansların artırmak istemektedir.

$\mathrm{Bu}$ çalışma Türkiye tekstil sektörü işletmelerinin, girişimci yönlülük ve içgirişimcilik faaliyetlerinin işletme performansı arasındaki ilişkiyi belirlemeye yönelik görgül bir çalışmayı amaçlamaktadır. Girişimci yönlülük, iç-girişimcilik ve işletme performansı olarak üç boyutlu tasarlanan çalışma, İstanbul Sanayi Odası (İSO-500) listesinde yer alan 96 tekstil sektörü işletmelerine anket göndermek suretiyle yapılmıştır. Ancak araştırmaya 51 işletme katılmış ve 51 işletmeden gelen veriler, SPSS 11. ve 8.7 Lisrel istatistiki programlar yardımıyla değerlendirilmiştir.

\section{KAVRAMSAL/KURAMSAL ÇERÇEVE}

a) Girişimci Yönlülük: Yeni rekabet koşulları işletmeleri değişime zorlamakta, faaliyetlerini girişimci yönlülük çerçevesinde düzenleme ihtiyacı yaratmaktadır. Bu durum işletmelerin önüne çok sayıda firsatı da ortaya çıkarmaktadır. (Papatya, 2007; Antoncic, Hisrich, 2000)

Girişimci yönlülük işletmenin rekabetçi kaynakları üstünlük sağlayacak şekilde dönüştürme ve kârlılığını artırma, stratejik iş yenileme ve yeni pazar/lar yaratma konusunda zorunlu ve yenilikçi olanaklar sunmaktadır. (Papatya, 2006a; Alvarez, Busenit, 2001). Diğer bir deyişle girişimci yönlülük, yaratıcı süreçler üzerinden, arzulanan yenilik etkinliklerini planlama, tasarlama ve uygulama olanağ 1 veren, riskli ve pro-aktif davranış yoluyla değişimi niteleyen bir süreç olarak düşünülür. Dolayısıyla girişimci yönlülük, uzun erimli davranısssal bir nitelik taşımaktadır. (Echol, Neck, 1998; Morris, Donald, 1996).

Temelde girişimci yönlülük, rakiplere oranla etkin ve saldırgan davranışlar ile ilişkili bir kavramdır. Özellikle, işletmelerin olan/olası firsatları ele geçirme ve yeni ürün, hizmet, teknik ve/veya yöntemler üretme konusunda rakipleri izlemektense, rakiplerin avantaj sağlayan uygulamalarını etkisizleştirmeye veya yok etmeye ilişkindir (Zahra, Garvis, 2000). Bu açıdan girişimci yönlülük işletmenin yeni ürün, hizmet, teknik ve/veya yöntem tasarlama kapasitesini belirtir ve işletmenin yeni ürün geliştirmeiyileştirme, olan/olası sorunlara yeni ve güçlü çözümler üretme, yeni sistem ve yöntemler ortaya koyma konusunda rekabetçi bir strateji özelliği taşır (Naktiyok, 2004; Antoncic, Hisrich, 2000) Genellikle girişimci yönlülük için 5 alt boyut vurgulanır (Lumpkin, Dess, 1996). Bu boyutlar Tablo 1'de izlenebilir. 
PAPATYA, PAPATYA, HAMŞIOĞLU | Entrepreneurship Orientation, Intrepreneurship and...

Tablo 1. Girişimci Yönlülük Boyutlarının Ayrıntılı Özeti

\begin{tabular}{ll}
\hline Boyutlar & \multicolumn{1}{c}{ Açılama } \\
\hline $\begin{array}{l}\text { Yenilikçi uyum } \\
\text { (oryantasyon) }\end{array}$ & $\begin{array}{l}\text { Bu boyut, yeni fikirler, denenmemiş yeni ürünler/hizmetler veya } \\
\text { teknolojik ve sonuçlanabilen yaratıcı süreçler ile ilgilenmeyi ifade } \\
\text { eder. Daha özelde işletmelerin bu süreçleri desteklemeye ilişkin } \\
\text { yeteneklerini ve eğilimlerini yansıtır. }\end{array}$ \\
\hline Pro-aktiflik & $\begin{array}{l}\text { Bu boyut, işletmenin liderlik etme ve yenilik üretme yanında, pazara } \\
\text { yeni girişleri takip etmeyi vurgular. Süreçte pro-aktif olma, } \\
\text { sektördeki işletmelere teknoloji ve yönetim ile ilgili teknikleri, } \\
\text { üretilen yenilikleri, ürünleri/hizmetleri izlemektense, öncülük } \\
\text { yapmayı öngörür. }\end{array}$ \\
\hline Risk Alma & $\begin{array}{l}\text { Bu boyut, risk alma ve firsatları etkili bir şekilde takip etmeyi, } \\
\text { kaynaklara odaklanmayı ve cesur adımlar atmayı ifade eder. Ayrıca } \\
\text { risk almada çevresel faktörlerin yeniden tanımlanmasını ve sürekli } \\
\text { bilgi toplanmasını amaç edinir. Bu şekilde riskin azalabileceği } \\
\text { vurgulanır. Ancak henüz ortaya konmamış firsatların belirlenmesi ve } \\
\text { ona göre kaynak kullanımının da, bir risk içerdiği göz ardı edilmez. }\end{array}$ \\
\hline Otonomi & $\begin{array}{l}\text { Bu boyut, rekabet boyunca çalışanların fikir ve görüşlerini özgürce } \\
\text { ifade etmelerini ve çalışanların inisiyatif kullanma konusunda yazılı } \\
\text { kurallara çok bağlı olmasını ifade eder. }\end{array}$ \\
\hline Rekabetçi saldırganlık \\
(Agresiflik)
\end{tabular}

Kaynak: Bu tablo Lumpkin, Dess, 1996; Antoncic, Hisrich, 2003; Dickson, Giglierano, 1986; Covin, Slevin, 1991; Barrett, Weinstein, 1998‘den yararlanarak hazırlanmıştır.

b) Iç-girişimcilik: Yapılan çalışmalarda, iç-girişimciliği tanımlamak ve içgirişimciliğin girişimci yönlülük ile farklı yönlerini vurgulamak için, birçok kavram kullanılır. En dikkat çekici olanları; kuramsal girişimcilik (Bulgerman, 1983, 1984), yeni kurumsal girişimcilik (Krueger, Brazeal, 1994), girişimci organizasyon (Hanan, 1976; Stevenson, Jarillo, 1990), işletme düzeyli girişimcilik (Lumpkin, Dess, 1996)'dir. Her ne kadar bu kavramlar iç-girişimciliğin değişik noktalarını vurgulamaya dönük olsa da, kabul edilebilir/mutlak bir tanım vermekten uzaktır. (Hornsby vd., 2002: 254-255). $\mathrm{Bu}$ açıdan kavramın yaygın olarak benimsenen ve kabul edilebilir bir tanımının yapılmasına büyük ihtiyaç vardır (Gautam, Verma, 1997). Birbiri ile ilintili bu iki kavram arasındaki temel farklılıklar Tablo 2'de izlenebilir. 
Tablo 2. İç Girişimcilik ve Girişimci Yönlülük Arasındaki Temel Farklar

\begin{tabular}{|c|c|c|}
\hline Ölçüt & İç Girişimcilik & Girișimci Yönlülük \\
\hline Anlayış & $\begin{array}{l}\text { Rekabetçi pozisyon geliştirme konusunda, } \\
\text { teknoloji ve yönetim stratejileri geliştirme } \\
\text { ve yönelimi sürdürme. }\end{array}$ & $\begin{array}{l}\text { Karşılaşılan tehditleri karşılamaya } \\
\text { yönelik, yaratıcı öneriler değerlendirme. }\end{array}$ \\
\hline Yaklaşım & $\begin{array}{l}\text { Rekabet üstünlüğü yaratmak ve } \\
\text { sürdürmek için, pazar ve sektör amaçları } \\
\text { ile eşgüdümlü çalışmaları gerçekleştirme. }\end{array}$ & $\begin{array}{l}\text { Rekabetçi olmak için, işin stratejik } \\
\text { yenilenmesi ve yeni pazar alanları } \\
\text { yaratmaya dönük yaratıcı süreç geliştirme. }\end{array}$ \\
\hline Yöneliş & $\begin{array}{l}\text { Yeni kaynak birleşim yolları ile uygun } \\
\text { yetenek ve firsat alanlarını genişletme. }\end{array}$ & $\begin{array}{l}\text { Girişimsel yönü desteleyen stratejik karar } \\
\text { alma tarzları, yöntemleri ve uygulamaları } \\
\text { geliştirme. }\end{array}$ \\
\hline Eylem & $\begin{array}{l}\text { Yeni ürün ve hizmete yönelik fikirleri, } \\
\text { kazanca dönüştürme, bütünsel zorunlu- } \\
\text { etkileşimli çalş̧ma gerçekleştirme. }\end{array}$ & $\begin{array}{l}\text { Yeni süreçler ve uygulamalar konusunda, } \\
\text { uzun soluklu girişimsel davranış } \\
\text { geliştirme ve çalışma. }\end{array}$ \\
\hline
\end{tabular}

Kaynak: Bu Tablo Gürel, 2012; Zahra, 1991; Zahra, 1993a'dan yararlanarak düzenlenmiştir.

Genel anlamda iç-girişimcilik, yeniliğe dayanan ve işletmenin pazar kaynak konumlandırmasına ve yeni yetenek alanları yaratmasına ilişkin düşünülen, tüm yapılan ve/veya yapilmak istenen faaliyetleri çerçeveler. Bu çerçeveleme aynı zamanda işletme yenilik yeteneklerini vurgular ve bu işletme performansı için belirleyici nitelik taşır (Papatya, 2006a; Stopford, Baden-Fuller, 1994; Parker, 2011).

İç-girişimcilik, işletmenin sürekli değişen çevre koşullarında, daha etkili ve stratejik bakış açısı oluşturmaya yönelik yenilik üretme ve yetenek potansiyeli olarak değerlendirilebilir. Burada iç-girişimcilik, güçlü bir performans ile birlikte; (a) yenilik üretme yeteneği, (b) sürekli öğrenme ve öğrenileni süreçleyebilme kapasitesi ve (c) firsatları yakalayabilme olanağı olarak düşünülebilir (Papatya, 2006b; Papatya, 2005).

Diğer açıdan iç-girişimcilik, çevresel uyum ve esneklik ile firsatları ve yenilikleri yakalamak için, işletmenin kendini sürekli yenileme ve dönüştürme olanağı sağlar. Bu yenileme ve dönüştürme, işletme yapısı ile etkileşen bütün faaliyetleri kapsar ve işletmenin yetenekleri ile birebir etkileşir. Bu etkileşim, işletmenin yeniden/sürekli öğrenmesine ve işletme faaliyetlerine en uygun kaynak birikimi sağlanmasına katkıda bulunur. $\mathrm{Bu}$ nedenle iç-girişimcilik, işletmenin yeni firsatlar yaratmaya dönük faaliyetlerin yeniden süreçlenmesi olarak ifade edilir (Thornbery, 2001). Temel olarak da iç-girişimcilik, işletmenin yaşanan gelişim ve dönüşüme bağlı; (a) yapılması gerekli değişim ve yenilik çalışmalarına, (b) çağdaş yönetim ve uygulamalarına, (c) daha yaratıcı iş modellerine ve yenilikçi iş alanlarına ilişkin değerlendirilir (Kuratko $v d$., 1990). 
PAPATYA, PAPATYA, HAMŞIOĞLU | Entrepreneurship Orientation, Intrepreneurship and...

Tablo 3. İç-Girişimcilik Alt Boyutlarının Özeti

\begin{tabular}{|c|c|}
\hline Boyutlar & Açıklama \\
\hline $\begin{array}{l}\text { Yeni } \\
\text { İş Kurma }\end{array}$ & $\begin{array}{l}\text { Yeni iş alanları kurma, işletme yapısında yenilik olarak ifade } \\
\text { edilir. Yeni iş/işletme oluşturma özerk ve yarı özerk işletme } \\
\text { düzeyine bakılmaksızın, işletmede yeni iş oluşturma şeklinde } \\
\text { kendini gösterir. İşletmenin ürün ve hizmetleri yeniden } \\
\text { tanımlaması ve/veya yeni pazarlar geliştirmesi örgütsel yeniliğin } \\
\text { bir parçasını oluşturur. }\end{array}$ \\
\hline Stratejik Yenilenme & $\begin{array}{l}\text { İ̧sletme, rekabetçi yaklaşımları sürekli değiştirerek, pazar ve } \\
\text { sektördeki rakipler ile olan ilişkilerini yeniden tanımlamanın } \\
\text { yollarını arar. Stratejik yenilenme, işletmenin koruması ve } \\
\text { geliştirmesi gereken pozisyonu ve işletme-çevre arasındaki } \\
\text { stratejik görevi niteler. }\end{array}$ \\
\hline Yenilikçilik & $\begin{array}{l}\text { Ürün/hizmet ve süreç yenilikleri daha çok işletmenin teknolojik } \\
\text { yenilikleri olarak karşımıza çıar. Bu daha çok, yeni ürün } \\
\text { geliştirme, mevcut ürün düzenleme ve yeni üretim } \\
\text { yöntemleri/süreçleri geliştirme şeklindedir. İşletme teknolojik- } \\
\text { yenilik hareketleri ile yeni ürün ve hizmetlerin çeşitlenmesini ve } \\
\text { artmasını sağlar. }\end{array}$ \\
\hline Üst Yönetimin Desteği & $\begin{array}{l}\text { İşletme üst yönetimi iç-girişimcilik faaliyetlerini kolaylaştıran ve } \\
\text { destekleyen bir düşünce ve eylem yapısına sahip olması gerekir. } \\
\text { Yenilik için gerekli kaynakların tahsisi, etkinleştirilmesi ve } \\
\text { denetimi üst yönetimin sorumluluğudur. }\end{array}$ \\
\hline Organizasyon Yapıs1 & $\begin{array}{l}\text { İç-girişimcilikte işletme organizasyonun (açık iletişim, kontrol } \\
\text { mekanizması, çevresel taramanın yoğunluğu ve organizasyonun } \\
\text { yapısı ve desteği) yaratıc1lığı ve yenilikçiliği destekleyecek şekilde } \\
\text { yapılanması, bölümler/birimler aras güçlü işbirliği olanaklarının } \\
\text { sağlanması, proje geliştirme ve uygulama hakkı tanınması, } \\
\text { geliştirici ortamın hazırlanması olarak ifade edilir. }\end{array}$ \\
\hline
\end{tabular}

Kaynak: Bu tablo Antoncic, Hisrich, 2001; Covin, Miles, 1999; Antoncic, Hisrich, 2003; Hornsby $v d$., 2002'den yararlanarak hazırlanmıştır.

İşletmelerin iç-girişimcilik faaliyetlerini yerine getirirken, bazı düzenleme ve uyumlaştırma çabalarını gerçekleştirmesi beklenir. Özellikle, yenilik üretme, riske katlanma, yeni ürün/süreç geliştirme ve farklılaşma gibi bu çabalar kritik önem taşır. (Papatya vd., 2006). Bu açıklamalar 1şığında iç-girişimcilik, işletmenin bütününe yayılan bir süreç olarak, "yeni iş kurma, stratejik yenilenme ve yenilikçilik" gibi 3 temel alt boyut itibariyle değerlendirilebilir. (Zahra, 1993a; Antoncic, Hisrich, 2001) Ancak işletme bu alt boyutları gerçekleştirmek için, "üst yönetim desteğgi" boyutunu sağlaması önkoşul olarak karşımıza çıkar (Hornsby vd., 2002). Çünkü üst yönetim desteği boyutu olmaksızın, bir diğer boyut olan "organizasyon yapısı"nı ele almak mümkün değildir (Covin, Slevin, 1991 Miller, 1983; Naman, Slevin, 1993). İç-girişimciliğe ilişkin alt boyutlar Tablo 3'de özetlenmiştir. 
c) İşletme Performansı: İşletme performansı, girişimci yönlülük ve içgirişimcilik faaliyetleri ile yakından ilgilidir. Çünkü girişimci yönlülük, işletmenin rekabetçi avantaj yaratmak için, yeni ürün/hizmet yaratma, yeni pazar alanları oluşturma ya da yenilik üretme gücü verir. İşletmenin yenilik üretme gücü, süreçte risk alma ve yeni davranış geliştirme tarzını biçimler. Yanı sıra işletmenin yenilik üretme kararlarında ve pazara yeni girişlerin takibinde, pro-aktif olması temeldir. Pro-aktif olma, sektörde diğer işletmeleri izlemektense, öncülük yapmayı ifade eder. (Antoncic, Hisrich, 2003: 7-24)

İç-girişimcilik, işletmede kârlılık, yenilik, stratejik yenilenme, bilgi kazanımı ve işletme performansı için güçlü bir hareketlilik içerir. Bu hareketlilik, işletmenin rekabetçi avantaj yaratma, güçlendirme ve sürdürme konusunda, yenilik üretme yeteneğine odaklanma firsatı sağlar (Hornsby vd., 2002; Antoncic, Hisrich, 2004). Böylece yenilik üretme yeteneği, işletmeye hem rekabetçi avantaj sağlama olanağı, hem de performans ve kârlığı artırma firsatı yaratmış olur (Gatignon, Xuereb, 1997).

\section{YAZIN TARAMA BULGULARI}

Yazında girişimci yönlülük, iç-girişimcilik ve işletme performansı arasındaki ilişkiyi çeşitli yönlerden inceleyen bazı çalışmalar izlenmektedir (Burgelman, 1983; Guth, Ginsberg, 1990; Antoncic, Hisrich, 2001; Antoncic, Hisrich, 2003; Zahra, Garvis, 2000; Zahra, Covin, 1995; Lumpkin, Dess, 1996: Lumpkin, Dess, 2001; Zahra, 1993a; Zahra, 1993b; Zahra, 1993c; Zahra, 1991; Wiklund, Shepherd, 2005). Türkçe yazında bu eksenli yapılan çalışmalar, 2005 yılı sonrası başladığı görülür. Ancak gerek kavramsal, gerekse girişimci yönlülüğün ve iç-girişimciliğin -kısmen veya tamamenişletme performansına olan etkisini incelemeye dönük kuramsal ve görgül çalışmaların yapılmasına ve genişletilmesine ihtiyaç vardır. (Bazı çalışmalar için $b k z$. Alpkan $v d$., 2005; Bulut, 2007; Fiş, 2009; Onay, Çavuşoğlu, 2010; Altuntaş, Dönmez, 2010; Gürel, 2011; Gürel, 2012; Demirel, Özbezek, 2015). Kaldı ki, bu zamana kadar yapılan yazınveritabanı taramasında, girişimci yönlülüğün ve iç-girişimciliğin birlikte araştırıldığı ve işletme performansı arasındaki ilişkiyi değerlendiren, kavramsal/kuramsal ve/veya görgül bir çalışmaya da rastlanmamıştır. Yapılan çalışmaların çoğunda, iki bağımsız değiş̧ken (girişimci yönlülük ve iç-girişimcilik) tek tek ele alınmış ve işletme performansına olan etkileri incelenmiştir.

$\mathrm{Bu}$ çalışmada ise, -çevresel unsurlar göz ardı edilerek- doğrudan iki bağımsız değişken birlikte ele alınmış ve işletme performansına olan/olası etkileri bütünsel olarak incelenmiştir. Böylece bundan sonraki yapılacak çalışmalarda, bu iki değişkenin işletme performansı üzerindeki etkileri -çevre unsurlarını da değerlendirmeye alarak- bütünsel incelebilirliğinin mümkün olduğu görülmüştür. 
PAPATYA, PAPATYA, HAMŞIOĞLU | Entrepreneurship Orientation, Intrepreneurship and...

Genel itibariyle yapılan çalışmalarda, girişimci yönlülüğün ve iç-girişimciliğin, işletme performansını (pro-aktiflik, risk alma, yeni ürün ve süreçleri itibariyle) olumlu etkilediği ve artırdığı vurgulanır. İşletme performansı ölçümü için de, yatırım, sermaye ve varlık kârlılıkları, satışlardaki artış, pazar payı büyümesi gibi değişkenlerin kullanımının yaygın olduğu izlenir (Lumpkin, Dess, 1996; Zahra, Covin, 1995; Zahra, 1995; Kuratko vd., 1990).

Lumpkin ve Dess (1996)'in yaptığı çalışmada, girişimci yönlülük ve performans arasındaki ilişki, bir işletme davranışı olarak incelemiş ve işletmenin içinde olduğu sektörün, çevresel faktörlerin ve yönetsel özelliklerin girişimci yönlülüğü nasıl etkilediği vurgulanmıştır (Lumpkin, Dess, 1996).

Zahra (1993), farklı sektörlerde yaptığı çalışmada, girişimci davranışın, işletmenin satış gelirleri ve satışların büyümesi gibi finansal göstergelerin performans ile ilişkini incelemiştir. Yine benzer şekilde Zahra ve Covin (1995), 108 işletme üzerinde gerçekleştirdiği çalışmada, girişimci davranış ile işletme performansı arasında anlamlı bir ilişkinin var olduğunu ortaya koymuştur.

Wiklund ve Shepherd (2003)'un yaptı̆̆ çalışmada, küçük işletmelerde girişimci yönlülük ve işletme performansı arasındaki ilişki araştırılmış; İsveç'deki 413 küçük işletmede gerçekleştirilen çalı̧̧mada, finansal performans değişkenleri ile işletme performansı arasındaki ilişki değerlendirilmiş ve girişimci yönlülüğün performans üzerinde olumlu etkisi olduğu görülmüştür.

Alpkan ve arkadaşlarının (2005) yaptı̆̆ çalışmada, işletme girişimciliğinin (risk alma, proaktiflik, yenilikçilik eğilimi), işletme performansı üzerine etkileri incelenmiş ve değişkenlerin nitel ve nicel performans üzerinde kısmen etkilerinin olduğu ortaya konmuştur.

Bulut (2007)'un yaptı̆̆ çalışmada, girişimci yönlülük bileşenleri (risk alma, yenilikçilik, pro-aktiflik ve rekabetçi agresiflik eğilimi) ve girişimsel yönlülüğün finansal performans üzerindeki ilişkisi araştırılmış ve ilişkinin pozitif yönde etkili olduğu görülmüş̧ür.

Altuntaş ve Dönmez (2010)'in yaptığı çalışmada, girişimcilik yönelimi ile örgütsel performans ilişkisi, Çanakkale bölgesinde faaliyet gösteren otel işletmeleri üzerinde incelemiş ve girişimcilik yönelimi ile örgütsel performans arasında, pozitif bir ilişkinin var olduğu görülmüştür.

Onay ve Çavuşoğlu (2010)'nun yaptı̆̆ı çalışmada, örgütsel faktörlerin ve çevresel algının, iç-girişimciliğe olan etkisi ve iç-girişimciliğin de örgütsel performansa olan etkileri incelenmiş; çalışma sonucunda, örgütsel faktörlerin iç-girişimcilik üzerinde 
kısmen etkili olduğu, çevresel faktörlerin iç-girişimcilik üzerinde etkili olduğu ve içgirişimciliğin örgütsel performans üzerinde etkili olduğu görülmüştür.

Gürel (2011)'in yaptığı çalışmada, işletmenin dış çevresi ve örgüt içi çevrenin içgirişimcilik üzerindeki etkisi ile iç-girişimciliğin (yeni iş gelişimi, ürün/hizmet yeniliği, süreç yeniliği, kendi kendini yenileme, risk alma, pro-aktiflik agresif rekabetçilik) işletme performansı üzerindeki etkisi araştırılmış; işletme içi/dı̧̧ faktörlerin, içgirişimcilik üzerinde pozitif etkisinin bulunduğu ve iç-girişimciliğin de işletme performansı üzerinde olumlu etkisi olduğu görülmüştür.

Yazında yapılan çalışmalar bütünsel incelendiğinde, işletme performans ölçümü için bazen nesnel verilerin, bazen de öznel verilerin kullanıldı̆̆ görülür. Bunun ana nedeni işletme performansının karmaşık ve çok boyutlu bir nitelik taşıması ve ölçümünün zor ve konu hakkında kabul görmüş sistematik bir değerlendirme yapma olanağının rahat olmamasından kaynaklı düşünülebilir (Murphy vd., 1996; Beamon, 1999). Bu açıdan çalışmada nesnel performans ölçüm yöntemi zorluğuna bağlı, öznel performans ölçüm yöntemi kullanılmış ve öznel performans ölçüm yönteminin, nesnel performans ölçüm yönteminin bir ikamesi olarak kabul edilmiştir (Bontis $v d$., 2000; Bontis, 1998).

\section{ARAŞTIRMA}

a) Araştırmanın Amacı ve Kapsamı: Bu araştırma, girişimci yönlülük, içgirişimcilik ve işletme performansı arasındaki ilişkinin, Türkiye'de faaliyet gösteren tekstil sektörü işletmelerine yönelik değerlendirilen görgül bir çalışma olarak tasarlanmış ve uygulanmıştır.

Araştırmanın ana kütlesini, İSO-500 işletme listesinde yer alan tekstil sektöründe faaliyet gösteren 96 tekstil işletmesi oluşturmuştur. Araştırma verileri anket yöntemi ile toplanmış; anketler işletmelere gönderilmeden önce, işletmelerin yönetici düzeyleri incelenmiş ve araştırma üst-orta düzey yöneticilerin katılımı ile gerçekleştirilmiş̧ir.

96 işletmeye 2015 Şubat-Mart ayında faks ve e-mail yoluyla gönderilmiştir. Çalışmaya katılımı kabul eden 51 işletmeden anketin geri dönüşümü sağlamıştır. Yapılan telefon görüşmelerinde, anketin geri dönüşümü olmayan işletmelerden yeniden geri dönüşüm istenmiş; ancak, iş yoğunlukları, yetkisizlik, ilgisizlik gibi çeşitli nedenlerle, 45 işletme yöneticisi ankete katılamayacaklarını belirtmişlerdir. 43 işletmenin üst ve orta düzey yöneticisinden, 5 anket elde edilmiş ( $43 \times 5=215$ anket), 8 işletmede ise, üst düzey işletme yöneticileri çalışmaya katılmamış, bu işletmelerde orta düzey yöneticiler ankete katılmış, bu işletmelerden 3 'er ( $8 \times 3=24$ anket) anket elde edilmiştir. Ankete katılan 51 işletmelerden, toplamda 239 yöneticiden gelen anket elde edilmiştir. 
PAPATYA, PAPATYA, HAMŞIOĞLU | Entrepreneurship Orientation, Intrepreneurship and...

Çalışmada Türk tekstil sektörü işletmelerinden gelen farklı sayıda anketin analizini yapabilmek için aritmetik ortalama (averaj) hesaplanmış, tek bir veri olarak değerlendirilmiş ve analize dahil edilmiştir. Buna göre elde edilen sonuçlar, 51 işletme için değerlendirilerek yorumlanmıştır. Anketlerin geri dönüşüm oranı 51/96=0,53 (\% 53) olarak hesaplanmıştır. ${ }^{1}$

b) Araştırmada Kullanılan Anketin Düzenlenmesi: Araştırma anketi, üç boyutlu olarak tasarlanmış, SPSS 11.5 ve Lisrel 8.7 istatistiki programlar yardımıyla Cronbach Alfa güvenilirlik değerleri hesaplanmış, bağımsız değişkenler arasında korelasyon incelenmiş ve elde edilen veriler doğrulayıcı faktör analizi ve yapısal eşitlik modeli ile analiz edilmiştir.

Üç boyutlu ve 5'li Likert sistemine bağlı tasarlanan anket şu şekildedir:

(i) Girişimci Yönlülük: Girişimcilik yönlülük, 5 alt boyut ile değerlendirilmiştir (Lumpkin, Dess, 1996). ${ }^{2}$ Uyum (oryantasyon) yenilikçilik, Miller, Friesen (1982) tarafından geliştirilen 3 madde ile; pro-aktiflik, Lumpkin, Dess (2001) tarafindan geliştirilen 3 madde ile; risk alma, Covin, Slevin (1989) ve Miller, Friesen (1982) tarafindan geliştirilen 3 madde ile; rekabetçi agrasiflik, Lumpkin ve Dess (2001) tarafında geliştirilen 3 madde ile ölçülmüştür. Otonomi ise, Shane vd. (1995) tarafindan geliştirilen 4 madde ile ölçülmüştür.

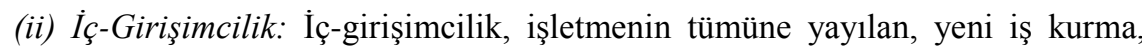
stratejik yenilenme ve yenilikçilik gibi alt boyutlardan oluşmaktadır. (bkz. Zahra, Garvis, 2000; Antoncic, Hisrich, 2001) Yeni iş kurma, Zahra (1993a) tarafindan geliştirilen 5 madde ile; stratejik yenilenme, Antoncic, Hisrich (2001) tarafindan geliştirilen 6 madde ile; ve yine yenilikçilik de, Antoncic, Hisrich (2001) tarafindan geliştirilen 6 madde ile ölçülmüştür.

$\mathrm{Bu}$ çalışmada, iç-girişimciliği etkileyen ve iç-girişimciliğin ortaya çıkmasında en önemli faktör olarak, üst yönetimin desteği (Hornsby vd., 2002; Zahra, 1991), Hornsby, vd. (2002) tarafından geliştirilen 9 madde ile ölçülmüştür. Ayrıca bu çalışmada üst yönetimin desteği ile iç-girişimciliği etkileyen içsel faktörlerden biri olarak ortaya çıkan organizasyon yapısı (Covin, Slevin,1991; Miller, 1983; Naman, Slevin, 1993), Covin, Slevin (1989) tarafindan geliştirilen 7 madde ile ölçülmüştür.

(iii) Işsletme Performansı: Performans ölçeği, Morgan ve Vorhies (2001) tarafından geliştirilen 4 madde ile ölçülmüştür.

c) Araştırmanın Modeli ve Hipotezleri: Araştırma modeli ve oluşturulan hipotezler Şekil 1'de gösterilmiştir. 


\section{Şekil 1. Araştırma Modeli ve Hipotezler}

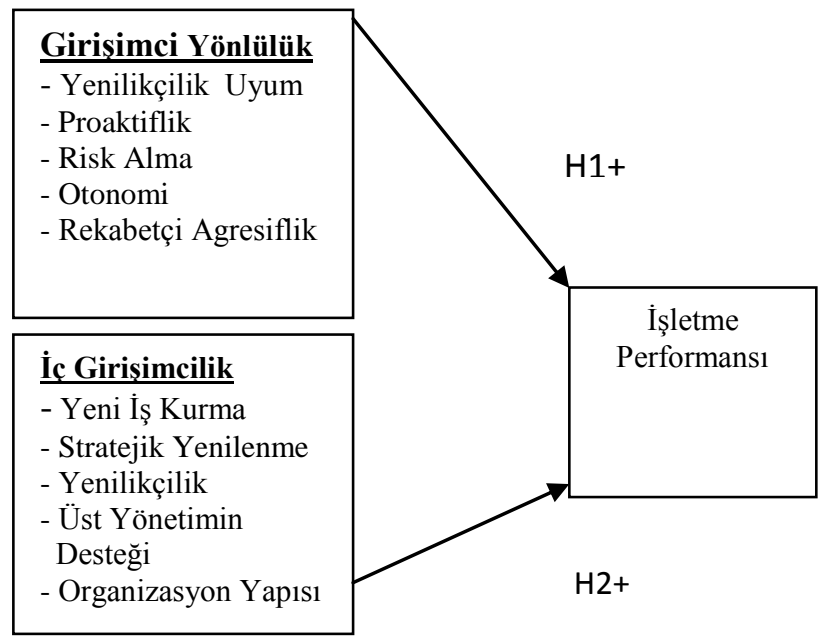

H1: Girişimci yönlülük işletme performansını pozitif yönde etkiler.

H2: İç-girişimcilik işletme performansını pozitif etkiler.

d) Modelin Test Edilmesi: Ortaya konan hipotezler doğrultusunda kavramsal/kuramsal olarak oluşturulan model, istatistikî teknik "Yapısal Eşitlik modeli (YEM)" ile test edilmiştir. Yapısal eşitlik modeli test edilmeden önce, modelde yer alan her bir örtülü değişkene ait ölçme modelleri "Doğrulayıcı Faktör Analizi (DFA)" ile test edilmiştir. Doğrulanan bu modeller doğrultusunda yapısal eşitlik modeli test edilerek hipotezler yorumlanmıştır.

Çalışmada kullanılan anketin güvenilirlik analizleri yapılmış ve analiz sonucunda, Cronbach Alpa Katsayıları değerlendirilmiştir. Buna göre; (a) üst yönetimin desteği, ,9131 (b) yeni iş kurma, ,7296 (c) stratejik yenilenme, ,8986 (d) yenilikçilik, ,7845 (e) otonomi, ,7973 (f) işletme performansı, ,8171 (g) uyum yenilikçiliği, ,8809 (h) pro-aktiflik, ,8503 (1) risk alma, ,7996 (i) rekabetçi agrasiflik, ,8982 (j) organizasyon yapısı, ,8914 yüksek düzeyde güvenilir çıkmıştır. Ayrıca çalışmada ele alınan bağımsız değiş̧kenler (girişimci yönlülük ve iç girişimcilik) arasında korelasyon sonuçları Tablo 4'de gösterilmiş̧ir.

Tablo 4. Bağımsız Değişskenler (Girişimci Yönlülük ve İç Girişimcilik) Arası Korelasyon

\begin{tabular}{|l|c|c|}
\hline & Girişimci Yönlülük & İç Girişimcilik \\
\hline Girişimci Yönlülük & $\mathbf{1}$ & $\begin{array}{c}(\mathrm{r}=, 738)^{* *} \\
, 000\end{array}$ \\
\hline İç Girişimcilik & $\begin{array}{c}\mathrm{r}=, 738)^{* *} \\
, 000\end{array}$ & $\mathbf{1}$ \\
\hline
\end{tabular}

**: Pearson Korelasyon $\mathrm{p}<0,01$ düzeyinde anlaml 
PAPATYA, PAPATYA, HAMŞIOĞLU | Entrepreneurship Orientation, Intrepreneurship and...

Tablo 4'de göre, bağımsız değişkenler girişimci yönlülük ve iç-girişimcilik arasında, yüksek düzeyde ve istatistikî olarak anlamlı bir ilişkinin olduğu görülmüştür.

(i) Doğrulayıcı Faktör Analizi: Doğrulayıcı faktör analizi, önceden tanımlanmış ve sınırlandırılmış bir yapının, bir model olarak doğrulanıp doğrulanmadığının test edildiği bir analizdir. Bu kapsamda, çalışmada doğrulayıcı faktör analizi, yapı geçerliliğini değerlendirmek amacıyla kullanılmıştır. (Çokluk vd., 2012: 275) Araştırmacılar tarafindan kültürler-arası anket uyarlama çalışmalarında, analizin doğrudan doğrulayıcı faktör analizi ile başlaması önerilmektedir. Çünkü söz konusu aracın özgün kültürdeki faktör deseni, çoğu kez nitel ve nicel araştırmayla ortaya konmuş ve aracın yapı geçerliliğine ilişkin deneysel kanıtlar belirlenmiş ve doğrulayıcı faktör analizi yapılmıştır (Çokluk vd., 2012: 283; Şimşek, 2007: 4).

- Girişimci Yönlülüğün Faktör Değişkenlerine Ait Doğrulayıcı Faktör Analizi: Girişimci yönlülük faktörlerini değerlendirmeye yönelik olarak 28 madde incelemeye alınmıştır. Yapılan ölçüm sonucunda istenilen faktör yük değerlerine sahip olmaması, modelin anlamlı t değerleri vermemesi ve hata varyanslarının çok yüksek olması nedeniyle, otonomi boyutundan 2 madde OTN2 ve OTN4, uyum yenilikçiliği boyutundan 3 madde ORY3, ORY4 ve ORY5, proaktiflik boyutundan 3 madde PRO1, PRO2 ve PRO5, risk alma boyutundan 3 madde RA1, RA4 ve RA6, rekabetçi agresiflik boyutundan 3 madde REA3, REA5 ve REA6 olmak üzere toplam 14 madde analizden çıkarılarak, ölçme modelleri tekrarlanmış ve anlamlı $\mathrm{t}$ değerleri veren maddeler ve uyum indekslerinin yeterli düzeyde olduğu ölçme modelleri analizde yer almıştır. Tablo 5 'de girişimci yönlülüğe ait faktörlerin açıklanma dereceleri gösterilmiştir. 
Girişimci Yönlülük, İç Girişimcilik ve İşletme...। PAPATYA, PAPATYA, HAMŞıOĞLU

Tablo 5. Girişimci Yönlülük Faktörlerinin Açıklanma Dereceleri

\begin{tabular}{|c|l|c|}
\hline $\begin{array}{c}\text { Soru } \\
\text { Kodu }\end{array}$ & \multicolumn{1}{|c|}{ Soru İfadeleri } & \multicolumn{1}{|c|}{$\begin{array}{c}\text { Açıklanma } \\
\text { Derecesi }\end{array}$} \\
\hline OTN1 & $\begin{array}{l}\text { Bir yeniliğin benimsenmesini kolaylaştırmak için personel ve prosedürler } \\
\text { devre dışı bırakılabilir }\end{array}$ & $0,86\left(\mathrm{R}^{2}=0,77\right)$ \\
\hline OTN3 & $\begin{array}{l}\text { Bir yeniliğe kaynak artırmak amacıyla bütçe/harcama ve kısıtlar devre dışı } \\
\text { bırakılabilir. }\end{array}$ & $0,78\left(\mathrm{R}^{2}=0,65\right)$ \\
\hline ORY1 & $\begin{array}{l}\text { Yönetim denenmiş ve başarılı olmuş ürün ve hizmetleri pazara sunmada } \\
\text { başarılıdır. }\end{array}$ & $0,69\left(\mathrm{R}^{2}=0,59\right)$ \\
\hline ORY2 & $\begin{array}{l}\text { Ürün/hizmet bazındaki değişiklikler daha çok küçük çaplı iyileştirmeler } \\
\text { şeklinde olmuştur. }\end{array}$ & $0,72\left(\mathrm{R}^{2}=0,66\right)$ \\
\hline ORY6 & $\begin{array}{l}\text { Ürün/hizmet bazındaki değişiklikler daha çok dramatik büyük çaplı } \\
\text { değişimler şeklinde olmuştur. }\end{array}$ & $0,87\left(\mathrm{R}^{2}=0,70\right)$ \\
\hline PRO3 & $\begin{array}{l}\text { Çok nadir olarak ürün ve hizmetlerin üretim teknolojilerinin ve idari teknik } \\
\text { yeniliklerin pazara sunulmasında öncüdür. }\end{array}$ & $0,88\left(\mathrm{R}^{2}=0,79\right)$ \\
\hline PRO4 & $\begin{array}{l}\text { Çok ssk olarak ürün/hizmetlerin üretim teknolojilerinin ve idari teknik } \\
\text { yeniliklerin pazara sunulmasında öncüdür. }\end{array}$ & $0,64\left(\mathrm{R}^{2}=0,57\right)$ \\
\hline PRO6 & $\begin{array}{l}\text { Yeni ürün ve fikirlerin pazara sunulmasında büyük oranda rakiplerin önünde } \\
\text { öncü olma eğilimindedir. }\end{array}$ & $0,70\left(\mathrm{R}^{2}=0,64\right)$ \\
\hline RA2 & $\begin{array}{l}\text { Üst yönetimin yüksek riskli (yüksek geri dönüşüm oranını yakalama şansı } \\
\text { bulunan) projelere güçlü bir yatkınlığı vardır. }\end{array}$ & $0,73\left(\mathrm{R}^{2}=0,68\right)$ \\
\hline RA3 & $\begin{array}{l}\text { Yönetim en iyi davranış biçiminin faaliyet gösterdiğimiz çevreyle ilişkili } \\
\text { olarak küçük ve yavaş adımlarla ilerlemek olduğuna inanır. }\end{array}$ & $0,66\left(\mathrm{R}^{2}=0,55\right)$ \\
\hline RA5 & Belirsizlik içeren durumlarda karar verirken "bekle gör” yaklaşımı uygulanır. & $0,74\left(\mathrm{R}^{2}=0,63\right)$ \\
\hline REA2 & I̧şletme fazlasıyla güçlü ve rekabette çok saldırgandır. & $0,80\left(\mathrm{R}^{2}=0,71\right)$ \\
\hline REA4 & Rakibini “yok et” ilkesiyle çok saldırgan bir tarzda hareket eder. & $0,79\left(\mathrm{R}^{2}=0,70\right)$ \\
\hline
\end{tabular}

Model kapsamında, girişimci yönlülüğü en çok açıklayan soru, PRO3 $\mathrm{R}^{2}=0,79$, en az açıklayan ise, RA3 $\mathrm{R}^{2}=0,55$ olduğu görülmüştür. Girişimci yönlülüğe ilişkin doğrulayıcı faktör analizi aşağıdaki Şekil 2'de gösterilmiştir. 
PAPATYA, PAPATYA, HAMŞIOĞLU | Entrepreneurship Orientation, Intrepreneurship and...

Şekil 2. Girişimci Yönlülüğe İlişkin Doğrulayıcı Faktör Analizi Sonuçları

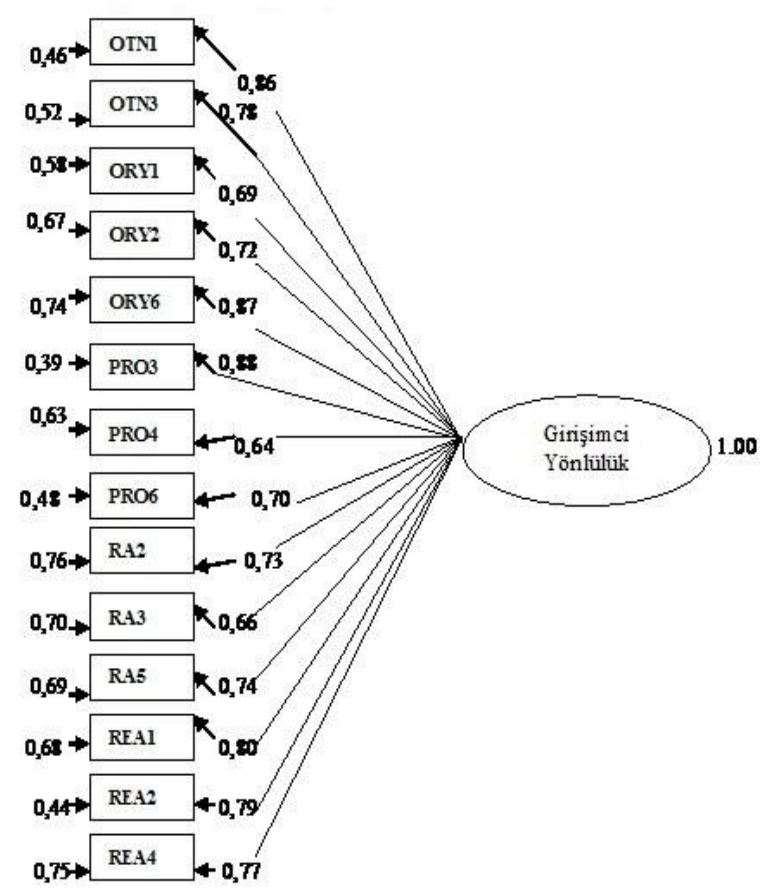

$\mathrm{Bu}$ faktörlere bağlı olarak gerçekleştirilen doğrulayıcı faktör analiz sonuçlarına göre, uyum indeksleri Tablo 6'da gösterilmiştir.

Tablo 6. Girişimci Yönlülüğe Ait Uyum İndeksleri

\begin{tabular}{|l|c|c|}
\hline Uyumluluk İndeksi & Performans & Kabul Edilebilir Uyum \\
\hline Mutlak Uyum Değeri & & \\
\hline Ki-Kare $\left(\mathrm{X}^{2}\right)$ & 84,36 & $1-5$ \\
\hline Serbestlik Derecesi & 39 & $0,90 \leq_{\mathrm{GFI}} \leq_{0,95}$ \\
\hline Ki-Kare/sd & 2,16 & $0,85 \leq_{\mathrm{AGFI}} \leq_{0,90}$ \\
\hline GFI & 0,94 & $0,05 \leq_{\mathrm{RMSR}} \leq_{0,08}$ \\
\hline AGFI & 0,88 & $0,05 \leq_{\mathrm{RMSEA}} \leq_{0,08}$ \\
\hline RMSR & 0,065 & $0,95 \leq_{\mathrm{CFI}} \leq_{0,97}$ \\
\hline RMSEA & 0,073 & $0,95 \leq_{\mathrm{NNFI}} \leq_{0,97}$ \\
\hline Artan Uyum Değeri & & $0,95 \leq_{\mathrm{NFI}} \leq_{0,97}$ \\
\hline CFI & 0,97 & \\
\hline NNFI & 0,97 & 0,96 \\
\hline NFI
\end{tabular}

Hacettepe University Journal of Economics and Administrative Sciences $\mid$

Vol 34, Issue 4, 2016

32 
Tablo 6'daki analiz sonucuna göre, girişimci yönlülük anketinin ki-kare değeri ve 39 serbestlik derecesinin birbirine oranı 2,16 olup, 3 değerinden küçük olması nedeniyle kabul edilebilir düzeyde olduğu görülmüştür. Uyum indeksi (GFI)'nın değeri, 0,94 olup kabul edilebilirliği iyi düzeydedir. Düzeltilmiş iyilik indeksi (AGFI)'nın değeri 0,88 olup kabul edilebilirliği iyi düzeydedir. RMSEA değeri 0,065 olup bu değer 0,08 den küçük olduğundan modelin kabul edilebilirliği için uygundur ve RMSR değeri 0,073 olup kabul edilebilirlikleri iyi düzeydedir. Artmalı uyum indeksi (CFI) 0,97 olup kabul edilebilirliği iyi düzeydedir. Normlaştırılmamış uyum indeksi (NNFI) 0,97 olup kabul edilebilirliği iyi düzeydedir. Normal fit indeksi (NFI) 0,96 olup kabul edilebilirliği iyi düzeydedir. Bu değerlere göre oluşturulan modelin uyum değerleri kabul edilebilirliği iyi düzeydedir (Schermelleh-Engel, Moosbrugger, 2003; Netemeyer vd., 2003; Bentler, 1990).

- İç Girişimcilik Faktör Değişkenlerine Ait Doğrulayıcı Faktör Analizi: İçgirişimcilik faktörlerini değerlendirmeye yönelik olarak 36 madde değerlendirmeye alınmıştır. Yapılan ölçüm sonucunda istenilen faktör yük değerlerine sahip olmaması, modelin anlamlı $\mathrm{t}$ değerleri vermemesi ve hata varyanslarının çok yüksek olması nedeniyle üst yönetim desteği boyutundan 4 madde ÜYD1, ÜYD2, ÜYD3 ve ÜYD6, yeni iş kurma boyutundan 1 madde YIK2, stratejik yenilenme boyutundan 3 madde STY3 STY4 ve STY6, yenilikçilik boyutundan 2 madde YE2 ve YE5 ve organizasyon yapis1 boyutundan 9 madde ORY2, ORY3, ORY5, ORY6, ORY8, ORY9 ORY10, ORY12 ve ORY13 olmak üzere toplam 19 madde analizden çıkarılarak, ölçme modelleri tekrarlanmış ve anlamlı $t$ değerleri veren maddeler ve uyum indekslerinin yeterli düzeyde olduğu ölçme modelleri analizde yer almıştır. Tablo 7'de iç girişimciliğe ait faktörlerin açıklanma dereceleri gösterilmektedir.

Model kapsamında iç-girişimciliği en çok açıklayan soru, UYD4 $\mathrm{R}^{2}=0,87$, en az açıklayan ise, ORY7 $\mathrm{R}^{2}=0,46$ olduğu görülmüştür. İç girişimciliğe ilişkin doğrulayıcı faktör analizi aşağıdaki Şekil 3'de gösterilmiştir. 
PAPATYA, PAPATYA, HAMŞIOĞLU | Entrepreneurship Orientation, Intrepreneurship and...

Tablo 7. İç Girişimcilik Faktörlerinin Açılanma Dereceleri

\begin{tabular}{|c|l|c|}
\hline $\begin{array}{c}\text { Soru } \\
\text { Kodu }\end{array}$ & \multicolumn{1}{|c|}{ Soru İfadeleri } & $\begin{array}{c}\text { Açılanma } \\
\text { Derecesi }\end{array}$ \\
\hline ÜYD4 & $\begin{array}{l}\text { Yeni ve yenilikçi fikirler geliştiren çalışanlar mali destek veya } \\
\text { terfi ile ödüllendirilirler. }\end{array}$ & $0,90\left(\mathrm{R}^{2}=0,87\right)$ \\
\hline ÜYD5 & $\begin{array}{l}\text { Başarılı yenilikçi projeler gerçekleştiren çalışanlar standart ödül } \\
\text { sisteminin dışında da ödüllendirilirler. }\end{array}$ & $0,85\left(\mathrm{R}^{2}=0,82\right)$ \\
\hline ÜYD7 & $\begin{array}{l}\text { Yöneticiler, çalışanların fikir ve önerilerine karş1 açık ve } \\
\text { saygılldırlar. }\end{array}$ & $0,79\left(\mathrm{R}^{2}=0,70\right)$ \\
\hline YÍK1 & Yeni pazar alanlarında ürünler için niş alanlar yaratma. & $0,68\left(\mathrm{R}^{2}=0,61\right)$ \\
\hline YİK3 & Endüstride yeni iş kollarını genişletmek. & $0,74\left(\mathrm{R}^{2}=0,63\right)$ \\
\hline YİK4 & $\begin{array}{l}\text { Reklam ve pazarlama gibi faaliyetlerle mevcut ürünlere yeni } \\
\text { talepler yaratma. }\end{array}$ & $0,63\left(\mathrm{R}^{2}=0,57\right)$ \\
\hline STY1 & İşletme misyonunu yeniden tanımlanması. & $0,70\left(\mathrm{R}^{2}=0,66\right)$ \\
\hline STY2 & Endüstrileri yeniden tanımlamak. & $0,64\left(\mathrm{R}^{2}=0,60\right)$ \\
\hline STY5 & Yaratıcıllk için sürekli teknik eğitim. & $0,60\left(\mathrm{R}^{2}=0,58\right)$ \\
\hline YEN1 & Yeni ürün aktivitelerini geliştirmede işletme yatırım yapar. & $0,67\left(\mathrm{R}^{2}=0,63\right)$ \\
\hline YEN3 & İşletme teknolojik yenilikleri yaratmada öncüdür. & $0,59\left(\mathrm{R}^{2}=0,49\right)$ \\
\hline YEN4 & İşletme ar-ge faaliyetlerini gerçekleştirmede liderdir. & $0,62\left(\mathrm{R}^{2}=0,55\right)$ \\
\hline YEN6 & Ürünleri ve üretim süreçlerini farklılaştırma. & $0,73\left(\mathrm{R}^{2}=0,64\right)$ \\
\hline ORY1 & İşletmede standart bir yönetim tarzı vardır & $0,56\left(\mathrm{R}^{2}=0,63\right)$ \\
\hline ORY4 & $\begin{array}{l}\text { İletişim kanalları çok açıktır. Önemli finansal ve operasyonel } \\
\text { bilgiler işletme içerisinde oldukça serbest bir şekilde dolaşır. }\end{array}$ & $0,62\left(\mathrm{R}^{2}=0,56\right)$ \\
\hline ORY7 & $\begin{array}{l}\text { İş koşullarındaki değişimleri yakalayabilmek için denenmiş ve } \\
\text { başarılı olmuş yönetim prensiplerinin uygulanmasına büyük } \\
\text { önem verilir. }\end{array}$ & $0,57\left(\mathrm{R}^{2}=0,46\right)$ \\
\hline ORY11 & $\begin{array}{l}\text { Gayri resmi sık1 olmayan kontrol mekanizması hakimdir ve } \\
\text { kişisel bilgiler ve işbirliği normları belirleyici rol oynar. }\end{array}$ & $0,71\left(\mathrm{R}^{2}=0,60\right)$ \\
\hline
\end{tabular}

Hacettepe University Journal of Economics and Administrative Sciences | 
Şekil 3. İç Girişimciliğe İliş̧kin Doğrulayıcı Faktör Analizi Sonuçları

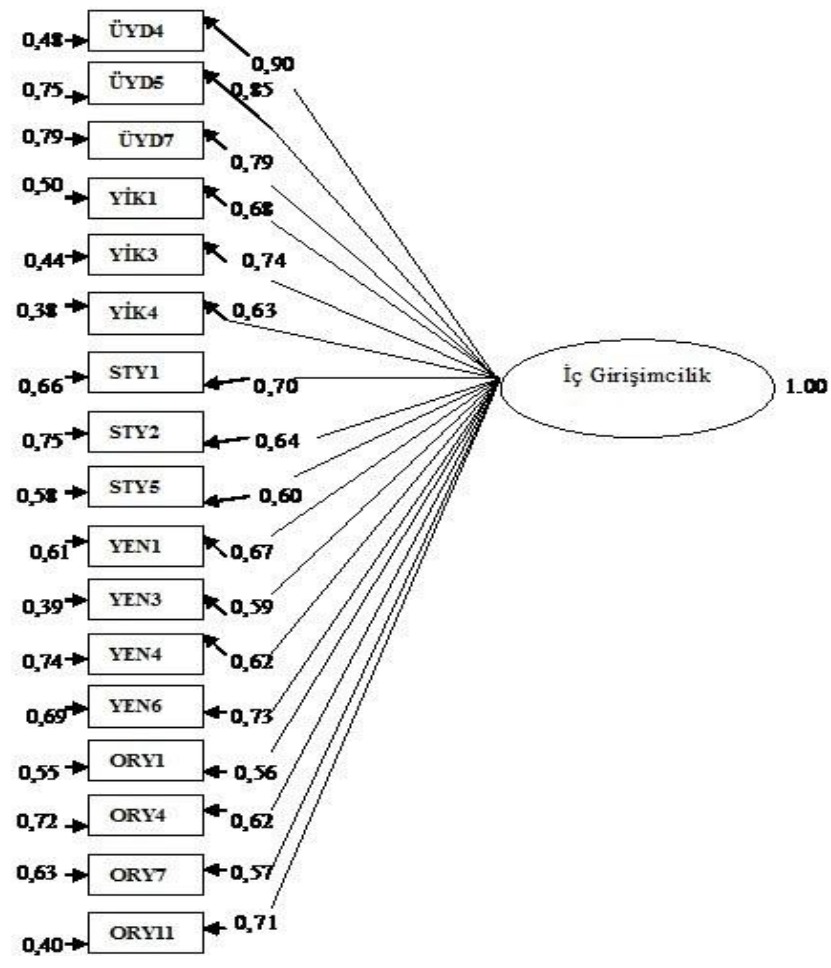

Bu faktörlere bağlı olarak gerçekleştirilen doğrulayıcı faktör analiz sonuçlarına göre uyum indeksleri Tablo 8'de gösterilmiştir.

Tablo 8. İç Girişimciliğe Ait Uyum İndeksleri

\begin{tabular}{|l|c|c|}
\hline \multicolumn{1}{|c|}{ Uyumluluk İndeksi } & Performans & Kabul Edilebilir Uyum \\
\hline Mutlak Uyum Değeri & & \\
\hline Ki-Kare $\left(\mathrm{X}^{2}\right)$ & 78,69 & $1-5$ \\
\hline Serbestlik Derecesi & 32 & $0,90 \leq_{\mathrm{GFI}} \leq_{0,95}$ \\
\hline Ki-Kare/sd & 2,45 & $0,85 \leq_{\mathrm{AGFI}} \leq_{0,90}$ \\
\hline GFI & 0,92 & $0,05 \leq_{\mathrm{RMSR}} \leq_{0,08}$ \\
\hline AGFI & 0,87 & $0,05 \leq_{\mathrm{RMSEA}} \leq_{0,08}$ \\
\hline RMSR & 0,040 & $0,95 \leq_{\mathrm{CFI}} \leq_{0,97}$ \\
\hline RMSEA & 0,068 & $0,95 \leq_{\mathrm{NNFI}} \leq_{0,97}$ \\
\hline Artan Uyum Değeri & & $0,95 \leq_{\mathrm{NFI}} \leq_{0,97}$ \\
\hline CFI & 0,95 & \\
\hline NNFI & 0,95 & \\
\hline NFI & 0,97 & \\
\hline
\end{tabular}


PAPATYA, PAPATYA, HAMŞIOĞLU | Entrepreneurship Orientation, Intrepreneurship and...

Tablo 8'deki analiz sonucuna göre, iç-girişimcilik anketinin ki-kare değeri ve 32 serbestlik derecesinin birbirine oranı 2,45 olup 3 değerinden küçük olması nedeniyle kabul edilebilir düzeyde olduğu görülmüştür. Uyum indeksi (GFI)'nın değeri 0,92 olup kabul edilebilirliği iyi düzeydedir. Düzeltilmiş iyilik indeksi (AGFI)'nın değeri 0,87 olup kabul edilebilirliği iyi düzeydedir. RMSEA değeri 0,068 olup bu değer 0,08 den küçük olduğundan modelin kabul edilebilirliği için uygundur ve RMSR değeri 0,040 olup kabul edilebilirlikleri iyi düzeydedir. Artmalı uyum indeksi (CFI) 0,95 olup kabul edilebilirliği iyi düzeydedir. Normlaştırılmamış uyum indeksi (NNFI) 0,95 olup kabul edilebilirliği iyi düzeydedir. Normal fit indeksi (NFI) 0,97 olup kabul edilebilirliği iyi düzeydedir. Bu değerlere göre oluşturulan modelin uyum değerleri kabul edilebilirliği iyi düzeydedir (Schermelleh-Engel, Moosbrugger, 2003; Netemeyer vd,, 2003; Bentler, 1990).

- Performans Faktör Değişkenlerine Ait Doğrulayıcı Faktör Analizi: Performans faktörleri değerlendirmeye yönelik olarak 4 madde değerlendirmeye alınmıştır. Yapılan ölçüm sonucunda istenilen faktör yük değerlerine sahip olmaması, modelin anlamlı t değerleri vermemesi ve hata varyanslarının çok yüksek olması nedeniyle performans boyutundan 1 madde PER3 analizden çıkarılarak, ölçme modelleri tekrarlanmış ve anlamlı $\mathrm{t}$ değerleri veren maddeler ve uyum indekslerinin yeterli düzeyde olduğu ölçme modelleri analizde yer almıştır. Tablo 9'da performansa ait değişkenlerin açıklanma dereceleri gösterilmektedir.

Tablo 9. Performans Faktörlerin Açıklanma Dereceleri

\begin{tabular}{|l|l|c|}
\hline Soru Kodu & \multicolumn{1}{|c|}{ Soru İfadeleri } & Açıklanma Derecesi \\
\hline PER1 & Rakiplerimize oranla pazar payımız daha iyidir. & $0,79\left(\mathrm{R}^{2}=0,75\right)$ \\
\hline PER2 & Rakiplerimize oranla satı̧ hacmimiz daha iyidir. & $0,82\left(\mathrm{R}^{2}=0,86\right)$ \\
\hline PER4 & Rakiplerimize oranla müşteri portföyümüz daha iyidir. & $0,77\left(\mathrm{R}^{2}=0,71\right)$ \\
\hline
\end{tabular}

Model kapsamında performansı en çok açıklayan soru, PER2 $\mathrm{R}^{2}=0,86$, en az açıklayan ise, PER4 $\mathrm{R}^{2}=0,71$ olduğu görülmüştür. Performansa ilişkin doğrulayıcı faktör analizi Şekil 4'de gösterilmiştir. 


\section{Şekil 4. Performans Değişkenlerine İliş̧kin Doğrulayıcı Faktör Analizi Sonuçları}

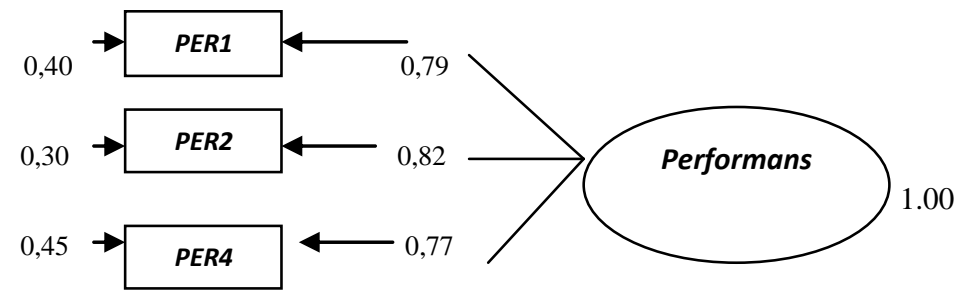

$\mathrm{Bu}$ faktörlere bağlı olarak gerçekleştirilen doğrulayıcı faktör analiz sonuçlarına göre uyum indeksleri Tablo 10’da gösterilmiştir.

Tablo 10. Performans Değişsenlerine Ait Uyum İndeksleri

\begin{tabular}{|c|c|c|}
\hline Uyumluluk İndeksi & Performans & Kabul Edilebilir Uyum \\
\hline \multicolumn{2}{|l|}{ Mutlak Uyum Değeri } & \\
\hline $\operatorname{Ki}-\operatorname{Kare}\left(\mathrm{X}^{2}\right)$ & 57,43 & \\
\hline Serbestlik Derecesi & 23 & \\
\hline Ki-Kare/sd & 2,49 & $1-5$ \\
\hline GFI & 0,93 & $0,90 \leq{ }_{\mathrm{GFI}} \leq 0,95$ \\
\hline AGFI & 0,89 & $0,85 \leq_{\mathrm{AGFI}} \leq 0,90$ \\
\hline RMSR & 0,043 & $0,05 \leq_{\mathrm{RMSR}} \leq 0,08$ \\
\hline RMSEA & 0,074 & $0,05 \leq \mathrm{RMSEA} \leq 0,08$ \\
\hline \multicolumn{2}{|l|}{ Artan Uyum Değeri } & \\
\hline CFI & 0,96 & $0,95 \leq{ }_{\mathrm{CFI}} \leq 0,97$ \\
\hline NNFI & 0,95 & $0,95 \leq_{\mathrm{NNFI}} \leq 0,97$ \\
\hline NFI & 0,96 & $0,95 \leq_{\mathrm{NFI}} \leq 0,97$ \\
\hline
\end{tabular}

Tablo 10'daki analiz sonucuna göre, performans ölçeğinin ki-kare değeri ve 23 serbestlik derecesinin birbirine oranı 2,49 olup 3 değerinden küçük olması nedeniyle kabul edilebilir düzeyde olduğu görülmüştür. Uyum indeksi (GFI)'nın değeri 0,93 olup, kabul edilebilirliği iyi düzeydedir. Düzeltilmiş iyilik indeksi (AGFI)'nın değeri 0,89 olup, kabul edilebilirliği iyi düzeydedir. RMSEA değeri 0,043 olup bu değer 0,08 den küçük olduğundan modelin kabul edilebilirliği için uygundu ve RMSR değeri 0,074 olup kabul edilebilirlikleri iyi düzeydedir. Artmalı uyum indeksi (CFI) 0,96 olup, kabul edilebilirliği iyi düzeydedir. Normlaştırılmamış uyum indeksi (NNFI) 0,95 olup kabul edilebilirliği iyi düzeydedir. Normal fit indeksi (NFI) 0,96 olup kabul edilebilirliği iyi düzeydedir. Bu değerlere göre oluşturulan modelin uyum değerleri kabul edilebilirliği iyi düzeydedir (Schermelleh-Engel, Moosbrugger, 2003; Netemeyer $v d$. ., 2003; Bentler, 1990). 
PAPATYA, PAPATYA, HAMŞIOĞLU | Entrepreneurship Orientation, Intrepreneurship and...

(ii) Doğrulayıcı Faktör Analizine İlişkin t-Değerleri ve Hata Varyansları: Sonuçlara genel olarak bakıldığında, girişimci yönlülük, iç-girişimcilik ve performans ölçeklerinin ki-kare değerleri ve serbestlik derecelerinin birbirine oranı 3 değerinden küçük bir değer aldığ1 gözlenmiştir. Üç ölçekte de RMSEA değerinin 0,08 den küçük olduğu, GFI, AGFI, CFI, NNFI ve NFI değerlerinin 0,90'a çok yakın ya da üstünde olduğu görülmüştür. Tüm uyum indekslerinin kabul edilebilirliği iyi düzeydedir. Dolayısıyla tüm ölçme modellerinin doğrulandığı görülmektedir. Doğrulanan ölçüm modeline ilişkin tüm değerler Tablo 11 'de gösterilmiştir.

Tablo 11. Doğrulayıcı Faktör Analizi İçin Standart Değer, Hata Varyansı, t-Değeri ve Açıklanan Oran

\begin{tabular}{|l|c|c|c|c|}
\hline \multicolumn{1}{|c|}{ Değişkenler } & $\begin{array}{c}\text { Standart } \\
\text { Değer }\end{array}$ & t- Değeri & $\begin{array}{c}\text { Hata } \\
\text { Varyansı }\end{array}$ & $R^{2}$ \\
\hline $\begin{array}{l}\text { OTN1 Bir yeniliğin benimsenmesini } \\
\text { kolaylaştırmak için personel ve prosedürler } \\
\text { devre dışı bırakılabilir. }\end{array}$ & 0,86 & 2,14 & 0,46 & 0,77 \\
\hline $\begin{array}{l}\text { OTN3 Bir yeniliğe kaynak artırmak } \\
\text { amacıyla bütçe/harcama ve kısıtlar devre dışı } \\
\text { bırakılabilir. }\end{array}$ & 0,78 & 4,05 & 0,52 & 0,65 \\
\hline $\begin{array}{l}\text { ORY1 Yönetim denenmiş ve başarılı olmuş } \\
\text { ürün ve hizmetleri pazara sunmada } \\
\text { başarılıdır. }\end{array}$ & 0,69 & 5,23 & 0,58 & 0,59 \\
\hline $\begin{array}{l}\text { ORY2 Ürün/hizmet bazındaki değişiklikler } \\
\text { daha çok küçük çaplı iyileştirmeler şeklinde } \\
\text { olmuştur. }\end{array}$ & 0,72 & 8,45 & 0,67 & 0,66 \\
\hline $\begin{array}{l}\text { ORY6 Ürün/hizmet bazındaki değişiklikler } \\
\text { daha çok dramatik büyük çaplı değişimler } \\
\text { şeklinde olmuştur. }\end{array}$ & 0,87 & 11,02 & 0,74 & 0,70 \\
\hline $\begin{array}{l}\text { PRO3 Çok nadir olarak ürün ve hizmetlerin } \\
\text { üretim teknolojilerinin ve idari teknik } \\
\text { yeniliklerin pazara sunulmasında öncüdür. }\end{array}$ & 0,88 & 9,84 & 0,39 & 0,79 \\
\hline $\begin{array}{l}\text { PRO4 Çok sık olarak ürün/hizmetlerin } \\
\text { üretim teknolojilerinin ve idari teknik } \\
\text { yeniliklerin pazara sunulmasında öncüdür. }\end{array}$ & 0,64 & 14,58 & 0,63 & 0,57 \\
\hline $\begin{array}{l}\text { PRO6 Yeni ürün ve fikirlerin pazara } \\
\text { sunulması̈nda büyük oranda rakiplerin } \\
\text { önünde öncü olma eğilimindedir. }\end{array}$ & 0,70 & 10.05 & 0,48 & 0,64 \\
\hline $\begin{array}{l}\text { RA2 Üst yönetimin yüksek riskli (yüksek } \\
\text { geri dönüşüm oranını yakalama şans1 } \\
\text { bulunan) projelere güçlü bir yatkınlı̆gı vardır. }\end{array}$ & 0,73 & 10.29 & 0,76 & 0,68 \\
\hline $\begin{array}{l}\text { RA3 Yönetim en iyi davranış biçiminin } \\
\text { faaliyet gösterdiğimiz çevreyle ilişkili olarak } \\
\text { küçük ve yavaş adımlarla ilerlemek } \\
\text { olduğuna inanır. }\end{array}$ & 0,66 & 7,98 & 0,70 & 0,55 \\
\hline $\begin{array}{l}\text { RA5 Belirsizlik içeren durumlarda karar } \\
\text { verirken "bekle gör” yaklaşımı uygulanır. }\end{array}$ & 0,74 & 8,45 & 0,69 & 0,63 \\
\hline
\end{tabular}

Hacettepe University Journal of Economics and Administrative Sciences |

Vol 34, Issue 4, 2016

38 
Tablo 11'in Devamı:

\begin{tabular}{|c|c|c|c|c|}
\hline $\begin{array}{l}\text { REA1 İşletme fazlasıyla güçlü ve rekabette } \\
\text { cok saldırgandır. }\end{array}$ & 0,80 & 17,05 & 0,68 & 0,71 \\
\hline $\begin{array}{l}\text { REA2 Rakiplerinden iş kapmak içim özel bir } \\
\text { caba harcamaz. }\end{array}$ & 0,79 & 12,07 & 0,44 & 0,70 \\
\hline $\begin{array}{l}\text { REA4 Rakibini "yok et" ilkesiyle çok } \\
\text { saldırgan bir tarzda hareket eder. }\end{array}$ & 0,77 & 11,36 & 0,75 & 0,61 \\
\hline $\begin{array}{l}\text { ÜYD4 Yeni ve yenilikçi fikirler } \\
\text { çalışanlar mali } \\
\text { ödüllendiririlirler. }\end{array}$ & 0,90 & 15,00 & 0,48 & 0,87 \\
\hline 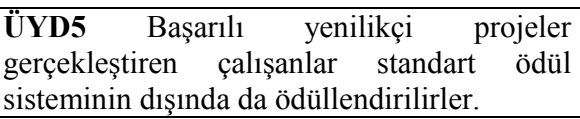 & 0,85 & 13,87 & 0,75 & 0,82 \\
\hline $\begin{array}{l}\text { ÜYD7 Yöneticiler, çalışanların fikir ve } \\
\text { önerilerine karşı açı ve saygılıdırlar. }\end{array}$ & 0,79 & 10,85 & 0,79 & 0,70 \\
\hline $\begin{array}{l}\text { YİK1 Yeni pazar alanlarında ürünler için niş } \\
\text { alanlar yaratma. }\end{array}$ & 0,68 & 14,54 & 0,50 & 0,61 \\
\hline $\begin{array}{l}\text { YİK3 Endüstride yeni iş } \\
\text { genişletmek. }\end{array}$ & 0,74 & 12,86 & 0,44 & 0,63 \\
\hline $\begin{array}{l}\text { YİK4 Reklâm ve pazarlama gibi faaliyetlerle } \\
\text { mevcut ürünlere yeni talepler yaratma. }\end{array}$ & 0,63 & 18,56 & 0,38 & 0,57 \\
\hline $\begin{array}{lll}\text { STY1 İşletme } & \text { misyonunu } & \text { yeniden } \\
\text { tanımlanması. } & & \\
\end{array}$ & 0,70 & 16,35 & 0,66 & 0,66 \\
\hline STY2 Endüstrileri yeniden tanımlamak. & 0,64 & 19,21 & 0,75 & 0,60 \\
\hline STY5 Yaratıcılık için sürekli teknik eğitim. & 0,60 & 9,74 & 0,58 & 0,58 \\
\hline $\begin{array}{l}\text { YEN1 Yeni ürün aktivitelerini geliştirmede } \\
\text { işletme yatırım yapar. }\end{array}$ & 0,67 & 13,56 & 0,61 & 0,63 \\
\hline $\begin{array}{l}\text { YEN3 İşletme teknolojik yenilikleri } \\
\text { yaratmada öncüdür. }\end{array}$ & 0,59 & 17,44 & 0,39 & 0,49 \\
\hline $\begin{array}{l}\text { YEN4 İşletme ar-ge } \\
\text { gerçekleştirmede liderdir. }\end{array}$ & 0,62 & 9,32 & 0,74 & 0,55 \\
\hline $\begin{array}{l}\text { YEN6 Ürünleri ve üretim süreçlerini } \\
\text { farklılaştırma. }\end{array}$ & 0,73 & 18,52 & 0,69 & 0,64 \\
\hline $\begin{array}{l}\text { ORY1 İşletmede standart bir yönetim tarzı } \\
\text { vardır. }\end{array}$ & 0,56 & 11,85 & 0,55 & 0,63 \\
\hline $\begin{array}{l}\text { ORY4 İletişim kanalları çok açıktır. Önemli } \\
\text { finansal ve operasyonel bilgiler işletme } \\
\text { içerisinde oldukça serbest bir şekilde dolaşır. }\end{array}$ & 0,62 & 15,49 & 0,72 & 0,56 \\
\hline $\begin{array}{l}\text { ORY7 İş koşullarındaki değişimleri } \\
\text { yakalayabilmek için denenmiş ve başarıll } \\
\text { olmuş yönetim prensiplerinin uygulanmasına } \\
\text { büyük önem verilir. }\end{array}$ & 0,57 & 8,69 & 0,63 & 0,46 \\
\hline $\begin{array}{l}\text { ORY11 Gayri resmi sık1 olmayan kontrol } \\
\text { mekanizması hakimdir. Kişisel bilgiler ve } \\
\text { işbirliği normları belirleyici rol oynar. }\end{array}$ & 0,71 & 7,01 & 0,40 & 0,60 \\
\hline $\begin{array}{l}\text { PER1 Rakiplerimize oranla pazar payımız } \\
\text { daha iyidir. }\end{array}$ & 0,79 & 3,78 & 0,40 & 0,75 \\
\hline $\begin{array}{l}\text { PER2 Rakiplerimize oranla satış hacmimiz } \\
\text { daha iyidir. }\end{array}$ & 0,82 & 6,05 & 0,30 & 0,86 \\
\hline $\begin{array}{lccc}\text { PER4 } & \text { Rakiplerimize } & \text { oranla } & \text { müşteri } \\
\text { portföyümüz daha iyidir. } & & \end{array}$ & 0,77 & 4,44 & 0,45 & 0,71 \\
\hline
\end{tabular}


PAPATYA, PAPATYA, HAMŞIOĞLU | Entrepreneurship Orientation, Intrepreneurship and...

Ölçme modelinin test edilmesinden sonra, kavramsal/kuramsal temele dayanarak oluşturan araştırma hipotezleri yapısal modelde test edilmiştir.

(iii) Araştırma Modeli Analiz Sonuçları: Doğrulayıcı faktör analizine göre test edilen yapısal model iyi uyum indeksleri vermiştir. Yapısal uyum indeksleri Tablo 12 'de gösterilmiştir.

Tablo 12. Yapısal Modele Ait Uyum İndeksleri

\begin{tabular}{|c|c|c|}
\hline Uyumluluk İndeksi & Performans & Kabul Edilebilir Uyum \\
\hline \multicolumn{3}{|l|}{ Mutlak Uyum Değeri } \\
\hline $\operatorname{Ki}$-Kare $\left(\mathrm{X}^{2}\right)$ & 380,95 & \\
\hline Serbestlik Derecesi & 160 & \\
\hline Ki-Kare/sd & 2,38 & $1-5$ \\
\hline GFI & 0,95 & $0,90 \leq{ }_{\mathrm{GFI}} \leq 0,95$ \\
\hline AGFI & 0,86 & $0,85 \leq_{\mathrm{AGFI}} \leq 0,90$ \\
\hline RMSR & 0,045 & $0,05 \leq_{\mathrm{RMSR}} \leq_{0,08}$ \\
\hline RMSEA & 0,076 & $0,05 \leq_{\mathrm{RMSEA}} \leq \leq_{0,08}$ \\
\hline \multicolumn{3}{|l|}{ Artan Uyum Değeri } \\
\hline CFI & 0,96 & $0,95 \leq \mathrm{CFI} \leq 0,97$ \\
\hline NNFI & 0,97 & $0,95 \leq \mathrm{NNFI} \leq 0,97$ \\
\hline NFI & 0,97 & $0,95 \leq_{\mathrm{NFI}} \leq 0,97$ \\
\hline
\end{tabular}

Tablo 12'deki yapısal modele ilişskin uyum indekslerine göre ki-kare değeri ve 160 serbestlik derecesinin birbirine oranı 2,38 olup 3 değerinden küçük olması nedeniyle kabul edilebilir düzeyde olduğu görülmüştür. Uyum indeksi (GFI)'nın değeri 0,95 olup, kabul edilebilirliği iyi düzeydedir. Düzeltilmiş iyilik indeksi (AGFI)'nın değeri 0,86 olup, kabul edilebilirliği iyi düzeydedir. RMSEA değeri 0,076 olup bu değer 0,08 den küçük olduğundan modelin kabul edilebilirliği için uygundu ve RMSR değeri 0,045 olup, kabul edilebilirlikleri iyi düzeydedir. Artmalı uyum indeksi (CFI) 0,96 olup kabul edilebilirliği iyi düzeydedir. Normlaştırılmamış uyum indeksi (NNFI) 0,97 olup kabul edilebilirliği iyi düzeydedir. Normal fit indeksi (NFI) 0,97 olup, kabul edilebilirliği iyi düzeydedir. Bu değerlere göre oluşturulan modelin uyum değerleri kabul edilebilirliği iyi düzeydedir (Schermelleh-Engel, Moosbrugger, 2003; Netemeyer $v d$., 2003; Bentler, 1990). Tablo 13'de ise modeldeki değişkenler arası ilişkiler gösterilmektedir.

Tablo 13. Değişkenler Arası ilişkiler

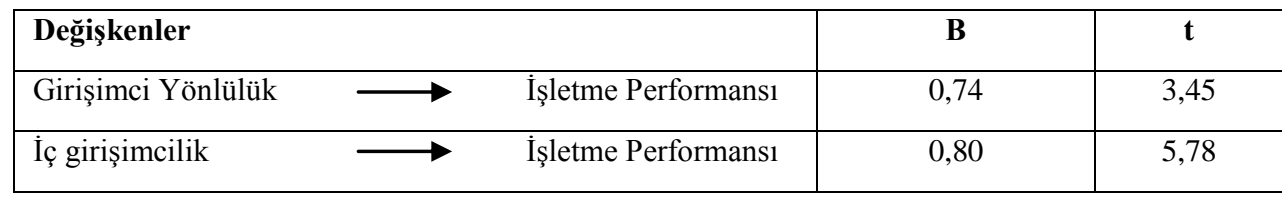

Hacettepe University Journal of Economics and Administrative Sciences | 
$\mathrm{Bu}$ sonuçlara göre, çalışmada oluşturulan hipotezlerin kabul edildiği görülmüş̧ür. Diğer bir deyişle, araştırmanın "girişimci yönlülük ile işletme performansinı pozitif etkiler" şeklinde oluşturulan birinci hipotez kabul edilmiştir. Standardize edilmiş yol katsayıları ( $\beta$ ) 0,74 olarak bulunmuş ve bu iki değişken arasında ki ilişkinin yüksek düzeyde ve anlamlı olduğu görülmüştür $(\beta 0,74 ; \mathrm{t}=3,45 ; \mathrm{p}<0,05)$. Bu değer, girişimci yönlülükteki bir puanlık artı̧ın, performans da 0,74 puanlık bir artışa veya bu durumun tam tersi bir puanlık azalışın performansta 0,74 puanlık bir azalışa neden olacağını ifade etmektedir. "Iç̧-girişsimlik, işletme performansını pozitif etkiler" şeklinde oluşturulan ikinci hipotez kabul edilmiştir. Standardize edilen yol katsayıları ( $\beta$ ) 0,80 olarak bulunmuş ve bu iki değişken arasındaki ilişkinin yüksek düzeyde ve anlamlı olduğu anlaşılmıştır $(\beta 0,80 ; \mathrm{t}=5,78 ; \mathrm{p}<0,05)$. Bu değer, iç-girişimcilikteki bir puanlık artışın, performansta 0,80 puanlık bir artışa veya bu durumun tam tersi bir puanlık azalışın performansta 0,80 puanlık bir azalışa neden olacağını ifade etmektedir.

Modelin yapısal eşitliği incelendiğinde, aşağıda verilen her iki denklemde de, açıklanan varyans oranlarının yüksek olduğu ve denklemde elde edilen $t$ değerlerinin anlamlı olduğu görülmüştür $(\mathrm{p}<0,05)$.

- Işsletme Performansı (Isl-Per) $=0,74 *$ Grr-Yon (Girişimci Yönlülük), Hata Varyansl $=0,35, R^{2}=0,70$

- İşletme Performansı (Isl-Per) $=0,80 * I c-$ Glr (Íç-Girişimcilik), Hata Varyansl $=0,28, R^{2}=0,76$

Yapısal modele ilişkin standardize edilmiş, yol katsayıları Şekil 5'de gösterilmiştir. 
PAPATYA, PAPATYA, HAMŞIOĞLU | Entrepreneurship Orientation, Intrepreneurship and...

Şekil 5: Araştırma Modeline İlişsin Yol Analizi

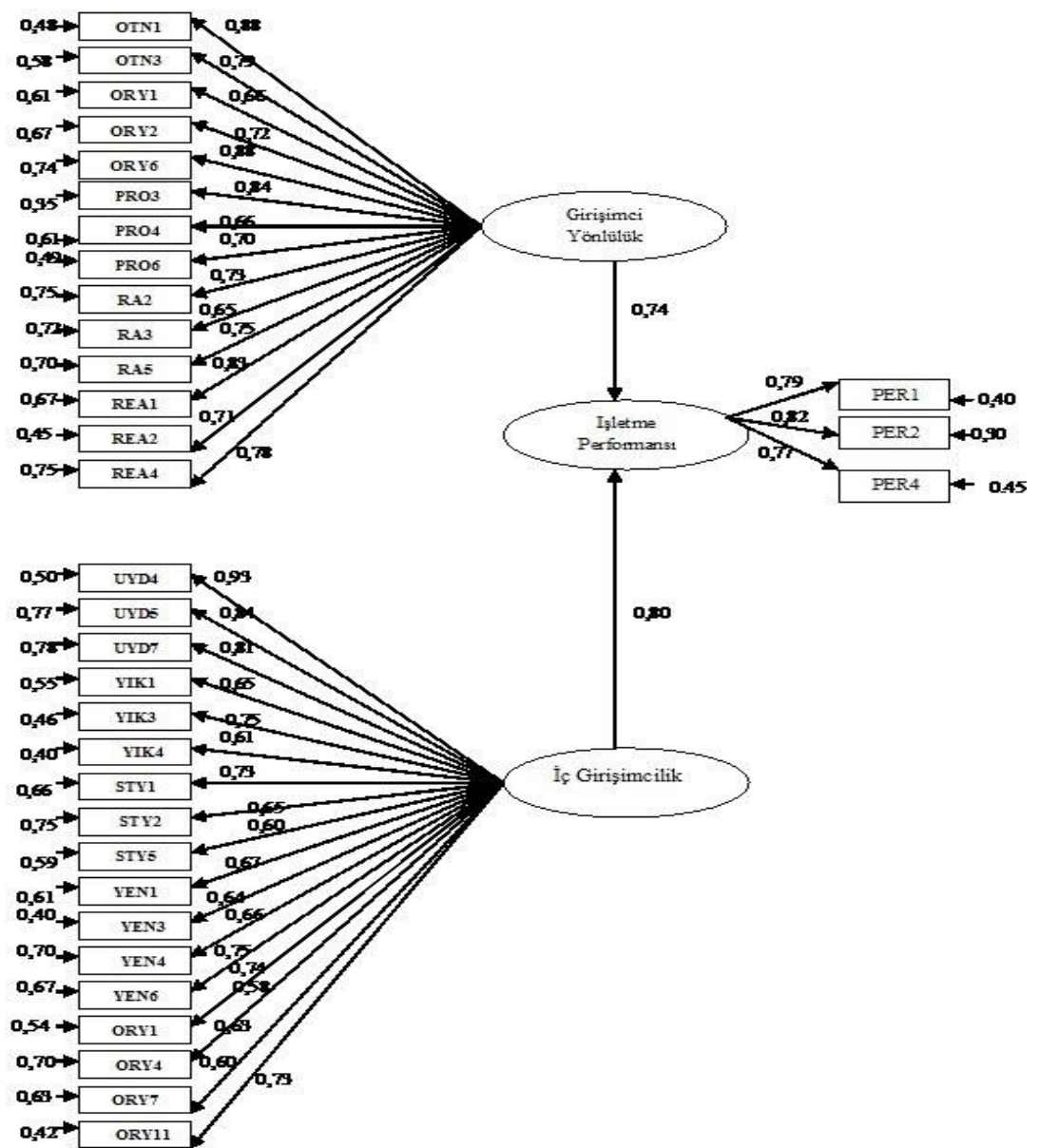

SONUÇ

Sonuç ve öneriler kısmını; araştırma bulgularının yazın değeri, işletme yöneticilerine ve gelecek araştırmalar için öneriler olarak 3 kategoride değerlendirmek mümkündür:

(a) Araştırma Bulgularının Yazın Değeri: Türkiye'de İSO-500 işletme listesinde yer alan ve ankete katılan 51 tekstil sektör işletmesinde, girişimci yönlülük ve iç girişimcilik ile işletme performansı arasındaki ilişki değerlendirilmiş; buna göre, araştırmada oluşturulan, hem "girişimci yönlülük işletme performansını pozitif etkiler" şeklinde birinci hipotez, hem de "iç-girişimcilik işletme performansını pozitif etkiler" 
şeklinde ikinci hipotez kabul edilerek, oluşturulan araştırma modeli doğrulanmıştır. Bu durum, yazında benzer araştırmalar ile -her ne kadar performans ölçüm değişkenleri farklı öngörülse de- eşgüdümlü (yani, girişimci yönlülüğün ve iç-girişimciliğin işletme performansı üzerinde etkili olduğu yönünde) bir sonuç ortaya koymuştur (Kuratko $v d$., 1990; Zahra, 1991, 1993a; Zahra, Covin, 1995; Zahra, Garvis, 2000; Lumpkin, Dess, 1996, 2001; Wiklund, Shepherd, 2003). Diğer bir deyişle, yazında bu yönlü yapılan araştırmalarda elde edilen sonuçlar, bir bakıma, bu çalışmanın sonuçlarını da destekler nitelikte olduğu izlenmiştir.

Temelde yapılan çalışmanın -özellikle Türkçe- yazına anlamlı bir katkı sağlayacağı umudu korunmuştur. Çalışmada girişimci yönlülük ve iç-girişimcilik alt boyutların tamamı işletme performansını etkilediği görülmüştür. Şu ana kadar yapılan genişletilmiş yazın taramasında da, girişimci yönlülüğün ve iç-girişimciliğin (bağımsız değişkenlerin) birlikte ele alınıp, işletme performansı üzerindeki etkilerini inceleyen bir çalışmaya rastlanmamıştır.

Yapılan bu çalışmada, iki bağımsız değişkenin işletme performansı üzerindeki çevresel faktörler veri kabul edilerek- etkisi olduğu görülmüsstür. Bu yönde yapılan genişletilmiş yazın taramasında da (Altuntaş, Dönmez, 2010; Alpkan vd., 2005; Antoncic, Zorn, 2004), iki bağımsız değişkenin birlikte incelendiği bir çalışmaya rastlanmamıştır. Bu açıdan çalışmanın yazına önemli bir katkı sağladığı düşünülmüştür. Bundan sonra yapılacak çalışmalarda, gerek göz ardı edilen çevresel faktörlerin dahil edilmesi, gerekse ele alınan değişkenlerin birlikte/bir bütün olarak işletme performansı üzerindeki etkilerinin incelenmesi mümkün görülmüştür.

(b) Yöneticiler İçin Bazı Öneriler: Günümüzde işletmeler, değişen bir çevrede faaliyetlerini sürdürmek için, mevcut rekabet koşullarına uyum sağlamak gibi bir zorunluluk ile karşı karşıyadır. Ancak bu zorunluluk beraberinde birçok firsatı da ortaya çıkardığı açıktır. Diğer bir deyişle, ortaya çıkan zorunluluk, işletmelere, yeni işbirliği, yeni proje, yeni ürün ve/veya hizmet oluşturma olanağı sağlama konusunda itici bir güç oluşturmaktadır.

Sürekli değişen rekabette işletmelerin girişimci yönlülük ve iç-girişimcilik faaliyetleri, gerek mevcut duruma uyum sağlamak, gerekse yeni ortaya çıkan firsatları yakalamak adına stratejik önem taşır. Dahası, işletmelerin faaliyet gösterdiği alanda, rakiplerine göre daha farklı olma, müşteri ihtiyaçlarını daha etkili karşılama ve rekabette öne çıkabilme durumu, girişimci yönlülüğe ve iç-girişimciliğe verdiği önem ile eşleşmektedir. İşletmelerin bu öneme bağlı performanslarını değerlendirmesi ve artırması beklenir. Bu bağlamda Türk Tekstil sektör işletme yönetimine/yöneticilerine şu iki yönde öneri verilebilir: 
PAPATYA, PAPATYA, HAMŞIOĞLU | Entrepreneurship Orientation, Intrepreneurship and...

- Üst ve orta düzey yöneticilerin, girişimci-stratejik bir işletme yapısı kazanabilmesi için, pro-aktif ve risk almaktan korkmayan bir tutum içinde olması gerekir. Ancak bu tutum, işletme yönetiminin mevcut rekabet koşullarını göz ardı etmesini engellememelidir.

- İşletme yönetimi yeni fikirlerin ve projelerin geliştirilmesi için, tüm çalışanları ile birlikte ortak bir akıl oluşturmalıdır. Böylece girişimci-stratejik yaklaşımın işletme çalışanları arasında benimsenmesi ve güçlü bir örgüt kültürünün oluşturulması sağlanabilir.

Ama her şeyden önce işletme yönetimin/yöneticilerinin, girişimci-stratejik yaklaşım için işletme kaynaklarının etkili tahsisi, kullanımı ve güçlendirilmesi gerekmektedir.

(c) Gelecek Araştırmalar için Bazı Öneriler: Araştırma bulguları yorumlanırken, bazı sınırlılıklar göz önünde tutulmuştur. Bu sınırlamalar, aynı zamanda gelecekte yapılacak araştırmalar için bazı öneri de içermektedir:

İlk olarak çalışmanın, tek bir sektörde ele alınmış olması, çalışmanın önemli bir kısıtı olarak, elde edilen sonuçların diğer sektörler için genelleştirilmesini engellemektedir. İkinci olarak, zaman kısıtı nedeniyle çalışmanın kesitsel olarak tasarlanmış olmasıdır. Dolayısıyla elde edilen sonuçların sağlaması, güçlendirilmesi ve daha geniş örneklem ile farklı sektörlerde -özellikle de rekabetin yoğun olduğu sektörlerde- karşslaştırmalı araştırmaların yapılması kısıtlanmıştır. Aynı zamanda çalışmada, öznel ölçütlerden çok, nesnel ölçütler ile ölçümün gerçekleştirilmesi, özellikle bağımsız değişkenlerin işletme performansı üzerinde etkili olabilecek iç-dış çevresel faktörlerin birlikte araştırmaya dahil edilmesi mümkün olmamıştır. Bu yüzden öne sürülen kısıtların, bundan sonra yapılacak araştırmalar ve araştırıcılar için, yararlı bir çalışma yapma çerçevesi olacağı düşünülmüştür.

\section{NOTLAR}

${ }^{1}$ Üst yönetimin katımları ile yapılan araştırmada ortalama \%20 yanıt oranı tatmin edici olarak kabul edilir Dolayısıyla bu araştırmada elde edilen cevaplama oranı yüksek düzeydedir (Menon $v d$., 1996: 304).

${ }^{2}$ Girişimci yönlülük anketi ilk kez Khandwalla tarafından ele alınmış ve değerlendirilmiş. Daha sonra birçok araştırmacı tarafindan bu anket ele alınarak geliştirilmiştir (Antoncic, Hisrich, 2001; Miller, Friesen, 1982; Covin, Slevin, 1989). 


\section{KAYNAKÇA}

Achrol, R., L. Stern (1988), "Environmental Determinants of Decision-Making Uncertainty in Marketing Channels", Journal of Marketing Research, 25(1), 25-36.

Alpkan L., E. Ergün, Ç. Bulut, C. Yılmaz (2005), "Şirket Girişimciliğinin Şirket Performansına Etkileri”, Doğuş Üniversitesi Dergisi, 6(2), 175-189.

Altuntaş G., D. Dönmez (2010), "Girişimcilik Yönelimi ve Örgütsel Performans İlişkisi: Çanakkale Bölgesinde Faaliyet Gösteren Otel İşletmelerinde Bir Araştırma”, İstanbul Üniversitesi İsletme Fakültesi Dergisi, 39(1), 50-74.

Alvarez, S.A., L.W. Busenit (2001), "The Entrepreneurship of Resource Based Theory”, Journal of Management, 27(6), 755-775.

Antoncic B., O. Zorn (2001), "The Mediating Role of Corporate Entrepreneurship in the Organizational Support-Performance Relationship: An Empirical Examination”, Managing Global Transitions, 2(1), 5-14.

Antoncic, B., R. Hisrich (2000), "Intrapreneurship Modeling in Transition Economies: A Comparison of Slovenia and the United States" Journal of Developmental Entrepreneurship, 5(1), 21-40.

Antoncic, B., R. Hisrich (2001), "Intrepreneurship: Construct Refinement and Cross-Cultural Validation”, Journal of Business Venturing, 16(5), 495-527.

Antoncic, B., R. Hisrich (2003), "Clarifying and Intrapreneurship Concept", Journal of Small Business and Entreprise Development, 10(1), 7-24.

Antoncic, B., R. Hisrich (2004),'Corporate Entrepreneurship Contingencies and Organizational Wealth Creation",Journal of Management Development, 23(6), 518-550.

Barrett, H., A. Weinstein (1998), "The Effect of Market Orientation and Organizational Flexibility on Corporate Entrepreneurship”, Entrepreneurship Theory and Practice, 23(1), 57-70.

Beamon, B.M. (1999), "Measuring Supply Chain Performance", Inertational Journal of Operations \& Production Management, 19(3), 275-292.

Bentler, P.M. (1990), “Comparative Fit Indexes in Structural Models”, Psychological Bulletin, 17(2), 238-246.

Bontis, N. (1998), "Intellectual Capital: An Exploratory Study that Develops Measures and Models", Management Decision, 36(2), 63-76.

Bontis, N., C.K. William, S. Richardson (2000), "Intellectual Capital and Business Performance In Malaysian Industries”, Journal of Intellectual Capital, 1(1), 85-100.

Bulu,t Ç. (2007), "Stratejik Oryantasyonlar ve Firma Performansı”, İzmit: Gebze Yüksek Teknoloji Enstitüsü Sosyal Bilimler Enstitüsü, Yayınlanmamış Doktora Tezi.

Burgelman, R.A. (1983), “Corporate Entrepreneurship and Strategic Management Insight from a Process Study”, Management Science, 29(12), 1349-1365.

Burgelman, R.A. (1984), "Designs for Corporate Entrepreneurship in Established Firms", California Management Review, 26(3), 155-166. 
PAPATYA, PAPATYA, HAMŞIOĞLU | Entrepreneurship Orientation, Intrepreneurship and...

Covin, J.G., M.P. Miles (1999), "Corporate Entrepreneurship and The Pursuit of Competitive Advantage", Entrepreneurship Theory and Practice, 23(3), 47-63.

Covin, J.G., P.D. Slevin (1991), "A Conceptual Model of Entrepreneurship as Firm Behaviour”, Entrepreneurship Theory and Practice, 16(1), 7-25.

Covin, J.G., P.D. Slevin (1989), "Strategic Management of Small Firms in Hostile and Benign Environments", Strategic Management Journal, 10(1), 75-87.

Çokluk, Ö., G. Şekercioğlu, Ş. Büyüköztürk (2012), "Sosyal Bilimler İçin Çok Değişkenli İstatistik SPSS ve LISREL Uygulamaları", Ankara: Pegem Akademi.

Demirel, Y., D. Özbezek (2015), "İ̧̧letmelerde İç Girişimcilik ve Yenilikçilik İlişkisine Yönelik Kavramsal Bir İnceleme”, TISK Akademi, 10(19), 112-135.

Dickson, P., J. Giglierano (1986), "Missing the Boat and Sinking the Boat: A Conceptual Model of Entrepreneurial Risk", Journal of Marketing, 50(3), 58-70.

Echols, A.E., C.P. Neck (1998), "The Impact of Behaviors and Structure on Corporate Entrepreneurial Success”, Journal of Managerial Psychology,13(1/2), 38-46.

Fiş, M.A. (2009), "Unlocking The Relationship Between Corporate Entrepreneurship and Performance", İstanbul: Sabancı Üniversitesi Sosyal Bilimler Enstitisü, Yayınlanmamış Doktora Tezi.

Gatignon, H., M.J. Xuereb (1997), "Strategic Orientation of the Firm and New Product Performance”, Journal of Marketing Research, 34(1), 77-90.

Gautam V., V. Verma (1997), “Corporate Entrepreneurship: Changing Perspectives”, Journal of Entrepreneurship, 6(2), 233-274.

Guth, W.D., A. Ginsberg (1990), “Guest Editors Introduction: Corporate Entrepreneurship”, Strategic Management Journal, 11(Summer), 5-15.

Gürel, E.B.B. (2011), "Firma Performansının Belirlenmesinde İç Girişimciliğin Rolü-ISO 500 Üzerine Bir Araştırma”, Finansal Politik \& Ekonomik Yorumlar Dergisi, 48(559), 99116.

Gürel, E.B.B. (2012), “İç Girişimcilik: Bir Literatür Taraması”, Gümüşhane Üniversitesi Sosyal Bilimler Elektronik Dergisi, 6(Haziran), 56-75.

Hanan, M. (1976), "Venturing Corporations -Thing Small to Stay Strong”, Harvard Business Review, 54(3), 139-148.

Hornsby, J., D. Kuratko, S. Zahra (2002), "Middle Managers Perception of the Internal Environment for Corporate Entrepreneurship: Assessing a Measurement Scale”, Journal of Business Venturing, 17(3), 253-273.

Krueger, N.F., D.V. Brazeal (1994), "Entrepreneurial Potential and Potential Entrepreneurs", Entrepreneurship Theory and Practice, 18(3), 91-104.

Kuratko, D.F., R.V. Montagno, J.S. Hornsby (1990), "Developing An Intrapreneurial Assessment Instrument For An Effective Corporate Entrepreneurial Environment”, Strategic Management Journal,11(Summer), 49-58.

Lumpkin, G.T., G.G. Dess (1996), "Clarifying the Entrepreneurial Orientation and Linking It to Performance", Academy of Management Review, 21(1), 135-172. 
Lumpkin, G.T., G.G. Dess, (2001), "Linking two Dimension of Entrepreneurial Orientation to Firm Performance: The Moderating Role of Environment and Industry Life Cycle", Journal of Business Venturing, 16(5), 429-451.

Menon, A., S.G. Bharadwaj, R. Howell (1996), "The Quality and Effectiveness of Marketing Strategy: Effect of Functional and Dysfunctional Conflict in Intraorganizational Relationship", Journal of the Academy of Marketing Science, 24(4), 299-313.

Miller, D. (1983), “The Correlates of Entrepreneurship In Three Types of Firms”, Management Science, 29(7), 770-791.

Miller, D., H.P. Friesen (1982), "Innovation in Conservative and Entrepreneurial Firms:Two Models of Strategic Momentum", Strategic Management Journal, 3(1), 1-25.

Morgan, N.A., D.W. Vorhies (2001), "Product Quality Aligment and Business Unit Performance", Journal of Product Innovation Management, 18(6), 396-407.

Morris, M., L.S. Donald (1996), “The Concept of Entrepreneurial Intensity: Implications for Company Performance”, Journal of Business Research, 36(1), 5-13.

Murphy, D., J.W. Trailer, R Hill (1996), "Measuring Organizational Performance in Entrepreneurship", Journal of Business Research, 36(1), 15-23.

Naktiyok, A. (2004), "İç Girişimcilik”, İstanbul: Beta.

Naman, L.J., P.D. Slevin (1993), "Entrepreneurship and The Concept of Fit: A Model and Empirical Tests", Strategic Management Journal, 14(2), 137-153.

Netemeyer, R., W.O. Bearden, S. Sharma (2003), "Scaling Procedures: Issies and Applications", U.S.A. 2nd Ed., Sage Publications, Thousand Oaks.

Onay, M., S. Çavuşoğlu (2010), "İşletmelerde Girişimcilik Özelliğini Etkileyen Faktörler: İç Girişimcilik”, Yönetim ve Ekonomi Dergisi, 17(1), 47-67.

Papatya, N. (2005), "Sürdürülebilir Başarı için İç-Girişimcilik” iç. A. Bozgeyik, Girişimcilere Yol Haritası, İstanbul: Hayat Yayıncılık No. 210/59, 83-87.

Papatya, G., N. Papatya, A.B. Hamşığlu (2006), “KOBİ'lerde İç-Girişimcilik Yönelimi: İçGirişimciliği Destekleyecek Alt Yapı Çalışmaları Üzerine Uygulama”, 17-18 Kasım, Istanbul 3. KOBI'ler ve Verimlilik Kongresi Bildiri Kitabı, 239-252.

Papatya, N. (2006a), "İşletmelerde Sıradışı Rekabet için Yenilikçi Pazarlama Yaklaşımı", Pazarlama Dünyası Dergisi, 20(4), 42-46.

Papatya, N. (2006b), "Pazarlamada Değişimin Ötesi: Yaratıcı ve Yenilikçi Pazarlama Dönüşümü", Pazarlama Dünyası Dergisi, 20(1), 73-77.

Papatya, N. (2007), "Sürdürülebilir Rekabetçi Üstünlük Sağlamada Stratejik Yönetim ve Pazarlama Odağı Kaynak Tabanlı Görüş -Kavramsal ve Kuramsal Yaklaşım”, Ankara: Asil.

Parker, S.C. (2011), "Intrapreneurship or Entrepreneurship?", Journal of Business Venturing, 26(1), 19-34.

Schermelleh-Engel, K., H. Moosbrugger (2003), "Evaluating the Fit of Structural Equation Models: Test of Significance and Descriptive Goodness-of-Fit Measures" Methods of Psychological Research Online , 8(2), 23-74. 
PAPATYA, PAPATYA, HAMŞIOĞLU | Entrepreneurship Orientation, Intrepreneurship and...

Shane, S., S. Venkataraman, I. MacMillan (1995), "Cultural Difference in Innovation Championing Strategies", Journal of Management, 21(5), 931-952.

Stevenson, H.H., J.C. Jarillo (1990), “A Paradigim of Entrepreneurship: Entrepreneurial Management”, Strategic Management Journal, 11(5), 17-27.

Stopford J.M., C.W.F. Baden-Fuller (1994), “Creating Corporate Entrepreneurship”, Strategic Management Journal, 15(7), 521-536.

Şimşek, Ö., F. (2007), Yapısal Eşitlik Modellemesine Giriş- Temel İlkeler ve Lirsel Uygulamaları, Ankara: Ekinoks.

Thornberry, N. (2003), "Corporate Entrepreneurship: Teaching Managers to be Entrepreneurs", The Journal of Management Development, 22(4), 329-344.

Wiklund, J., D.A. Shepherd (2005), "Entrepreneurial Orientation and Small Business Performance: A Configuration Approach”, Journal of Business Venturing, 20(1), 71-91.

Zahra, S., J.G. Covin (1995), "Contextual Influences on The Corporate Entrepreneurship Performance Relationship: A Longitudinal Analysis”, Journal of Business Venturing, 10(1), 43-58.

Zahra, S. (1991), "Predictors and Financial Outcomes of Corporate Entrepreneurship: An Exploratory Study", Journal of Business Venturing, 6(4), 259-285.

Zahra, S. (1993a), "Environment Corporate Entrepreneurship and Financial Performance: A Taxonomic Approach”, Journal of Business Venturing, 8(4), 319-340.

Zahra, S. (1993b), "New Product Innovation in Established Companies: Associations with Industry and Strategy Variables", Entrepreneurship Theory and Practice, 18(2), 47-67.

Zahra, S. (1993c), "Contextual Influences on the Corporate Entrepreneurship Performance Relationship: A Longitudinal Analysis”, Entrepreneurship Theory and Practice, 17(4), $5-21$.

Zahra, S. (1995), "Corporate Entrepreneurship and Financial Performance: The Case of Management Leveraged Buyouts”, Journal of Business Venturing, 10(3), 225-247.

Zahra, S., D. Garvis (2000), “International Corporate Entrepreneurship and Firm Performance: The Moderatıng Effect of International Environmental Hostility", Journal of Business Venturing, 15(5), 469-492. 